\title{
Electrochemically mediated precipitation of phosphate minerals for phosphorus removal and recovery: Progress and perspective
}

\author{
Yicheng Wang ${ }^{\text {b,c }}$, Philipp Kuntke ${ }^{\text {b,c }}$, Michel Saakes ${ }^{\mathrm{b}}$, Renata D. van der Weijden ${ }^{\mathrm{b}, \mathrm{c}}$, Cees J. \\ N. Buisman ${ }^{\text {b, }}$, Yang Lei ${ }^{\text {a,b,c,* }}$ \\ ${ }^{a}$ School of Environmental Science and Engineering, Southern University of Science and Technology (SUSTech), Shenzhen 518055, China \\ ${ }^{\mathrm{b}}$ Wetsus, Centre of Excellence for Sustainable Water Technology, P.O. Box 1113, 8900CC Leeuwarden, The Netherlands \\ ${ }^{\mathrm{c}}$ Environmental Technology, Wageningen University and Research, P.O. Box 17, 6700AA Wageningen, The Netherlands
}

\section{A R T I C L E I N F O}

\section{Keywords:}

Calcium phosphate

Struvite

(Bio)electrochemical systems

Organic phosphorus

Precipitation

Energy consumption

\begin{abstract}
A B S T R A C T
Phosphorus (P) is an essential element for the growth and reproduction of organisms. Unfortunately, the natural $\mathrm{P}$ cycle has been broken by the overexploitation of $\mathrm{P}$ ores and the associated discharge of $\mathrm{P}$ into water bodies, which may trigger the eutrophication of water bodies in the short term and possible P shortage soon. Consequently, technologies emerged to recover P from wastewater to mitigate pollution and exploit secondary P resources. Electrochemically induced phosphate precipitation has the merit of achieving P recovery without dosing additional chemicals via creating a localized high $\mathrm{pH}$ environment near the cathode. We critically reviewed the development of electrochemically induced precipitation systems toward P removal and recovery over the past ten years. We summarized and discussed the effects of $\mathrm{pH}$, current density, electrode configuration, and water matrix on the performance of electrochemical systems. Next to ortho P, we identified the potential and illustrated the mechanism of electrochemical P removal and recovery from non-ortho P compounds by combined anodic or anode-mediated oxidation and cathodic reduction (precipitation). Furthermore, we assessed the economic feasibility of electrochemical methods and concluded that they are more suitable for treating acidic P-rich waste streams. Despite promising potentials and significant progress in recent years, the application of electrochemical systems toward P recovery at a larger scale requires further research and development. Future work should focus on evaluating the system's performance under long-term operation, developing an automatic process for harvesting P deposits, and performing a detailed economic and life-cycle assessment.
\end{abstract}

\section{Introduction}

Phosphorus (P) is a fundamental element for organisms. It sculpts fauna and flora as genetic materials, cell structures, and bones (Cornel and Schaum, 2009; Schaum, 2018). Besides, it governs biological activities by participating in biochemical reactions as ATP (Desmidt et al., 2015). Notably, plants take up P from the soil while animals and humans supplement P through diet (Karunanithi et al., 2015). In the natural cycle, P originated from lithosphere and atmosphere would travel through biosphere and hydrosphere, and eventually returns to the soil in the form of organic fertilizer, establishing a closed cycle, as illustrated in the green lines of Fig. 1 (Cornel and Schaum 2009; Yuan et al., 2018). However, with the growth of the global food demand, intensive agricultural activities are required, which unidirectionally amplifies $P$ flow from soil to crops (Wang et al., 2018; Yuan et al., 2018). The P depletion in soil is compensated by P fertilizer. In addition, the need for other P-containing products, such as detergents, flame retardants, and fireworks, is also increasing with the expanding population (Chen and Graedel, 2016). The drastic increase of $P$ demand accelerates the exploitation of phosphate rock, which amplifies the P cycle, as emphasized in the red line of Fig. 1.

Unfortunately, phosphate rock is a non-renewable resource whose consumption pace has gone far beyond regeneration, and the $\mathrm{P}$ ores are regionally imbalanced (Cordell et al., 2009). If no actions are taken, the phosphate crisis might occur in the near future (Jasinski, 2020). Notably, the regional P balances in Latin America and the Caribbean, South Asia, Central and West Europe, and Oceania may lead to a shortage in 2022, according to the world fertilizer outlook 2022 from Food and Nations (2019).

Apart from scarcity at source, a more urgent problem is the $\mathrm{P}$ enrichment in downstream water bodies. The P fertilized in farmlands

\footnotetext{
* Corresponding author.

E-mail address: leiy3@sustech.edu.cn (Y. Lei).
} 


\begin{tabular}{|c|c|c|c|}
\hline \multicolumn{2}{|c|}{ List of abbreviation } & IEMs & ion exchange membranes \\
\hline ACF & activated carbon fiber & MFC & microbial fuel cell \\
\hline ACP & amorphous calcium phosphate & MMO & mixed metal oxide \\
\hline AEM & anion exchange membrane & $\mathrm{N}$ & Nitrogen \\
\hline BES & bioelectrochemical system & NOM & natural organic matter \\
\hline Ca-P & calcium phosphate & ORR & oxygen reduction reaction \\
\hline CEM & cation exchange membrane & $\mathrm{P}$ & phosphorus \\
\hline CPR & chemical phosphate removal & PEC & photo electrocatalytic cell \\
\hline EBPR & enhanced biological phosphorus removal & PGM & platinum group metal \\
\hline EMP & electrochemical mediated precipitation & RA & relative abundance \\
\hline ETs & electrochemical technologies & SI & saturation index \\
\hline Fe-P & iron phosphate & SSF & stainless steel foil \\
\hline HER & hydrogen evolution reaction & SSM & stainless steel mesh \\
\hline HAP & hydroxyapatite & TNA/NSS & $\mathrm{TiO}_{2} / \mathrm{Ni}-\mathrm{Sb}-\mathrm{SnO}_{2}$ \\
\hline
\end{tabular}

would leach and/or run-off into water bodies with rainfall (Chen and Graedel, 2016; Liu et al., 2020a). Meanwhile, P produced and consumed by human society eventually enters and accumulates in water bodies through urban sewage systems (Mayer et al., 2016). Because of the lack of $\mathrm{P}$ recycling, the $\mathrm{P}$ will find its destiny in water bodies. Surplus $\mathrm{P}$ in water bodies triggers eutrophication, causes oxygen depletion in water bodies and further the hypoxia of aquatic organisms (Karunanithi et al., 2015). Even though eutrophication may appear as a natural process, today, the frequent occurrence of algae blooms is attributed to human activities, especially the discharge of under-treated wastewater overloaded with $\mathrm{P}$ because $\mathrm{P}$ used to be the critical limiting nutrient in these water bodies.

Technologies have been developed to treat excess $\mathrm{P}$ in wastewater. One of the most widely accepted methods is chemical precipitation. During precipitation, reagents, such as iron, aluminum, magnesium, and calcium salts, are dosed to form less soluble or insoluble P minerals
(Nancharaiah et al., 2016; Ye et al., 2017). Adsorption is another common physicochemical method for $\mathrm{P}$ removal. Adsorption is easy to operate, but requirements for adsorbents are strict, such as high stability, reusability, and P affinity (Crini et al., 2019). Commercial processes based on physicochemical methods have been applied to remove $\mathrm{P}$ and other nutrients from wastewaters (Ghosh et al., 2019; Jupp et al., 2021; Li et al., 2019; Melia et al., 2017; Ye et al., 2017). Moreover, enhanced biological phosphorus removal (EBPR) could concentrate P from the liquid stream and is flexible to combine with other post-P recovery technologies (Egle et al., 2016; Perera et al., 2019). Overall, there is room for improvements in current $\mathrm{P}$ removal and recovery technologies, such as reducing chemical input, minimizing sludge processing, simplifying operation steps, and saving the organics consumed in EBPR process for energy production (i.e., biogas).

In recent years, electrochemical technologies (ETs) have received increasing attention in wastewater treatment (Garcia-Segura et al.,

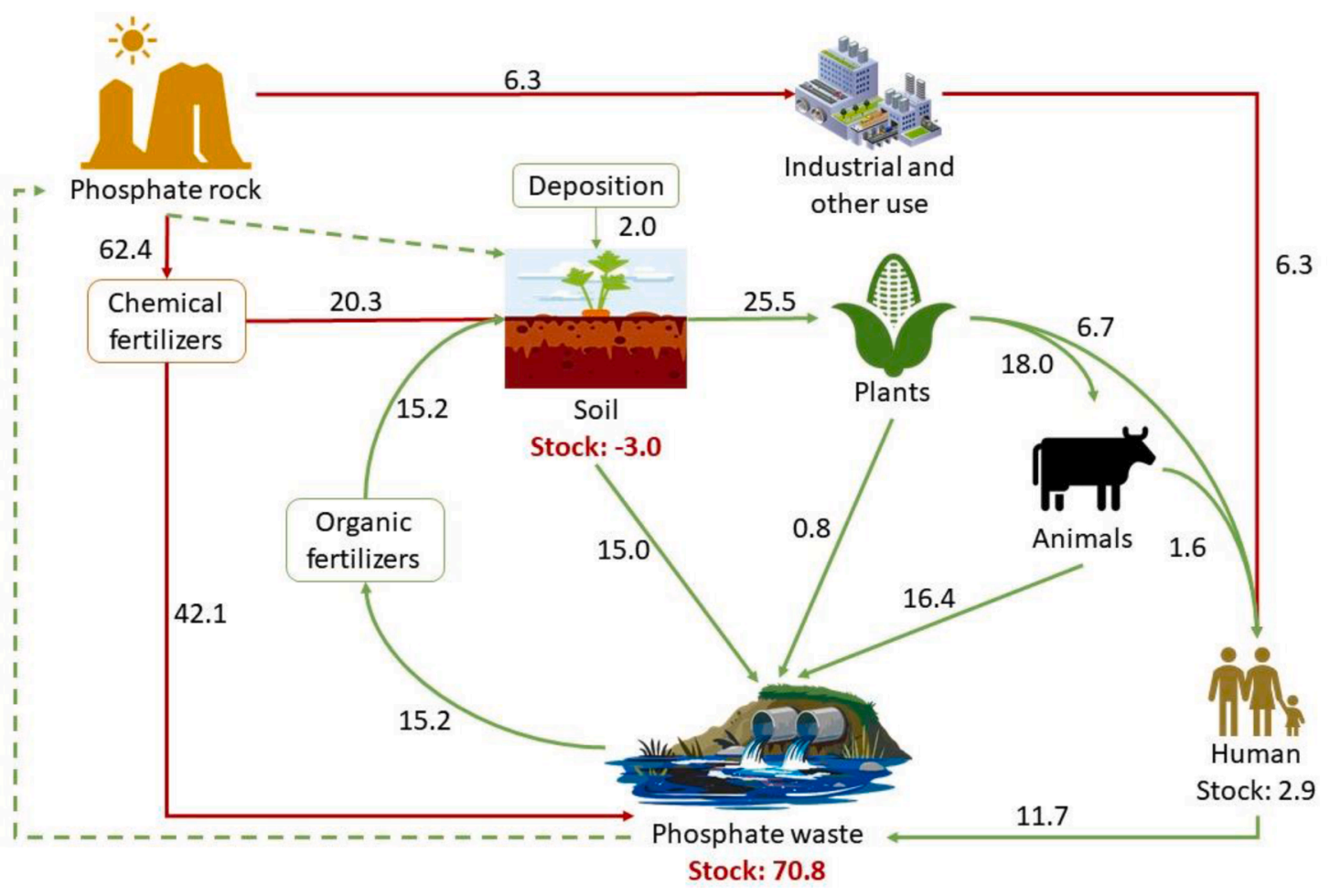

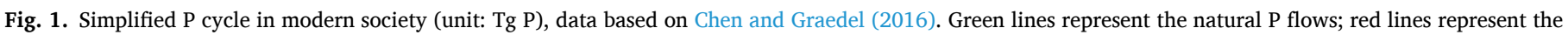
flows that have been amplified by human activities, the number of dot lines is negligible. 
2018; Modin and Gustavsson, 2014; Muddemann et al., 2019; Srivastava et al., 2020). Likewise, there is an increasing interest in applying electrochemically mediated precipitation (EMP) as a strategy to remove and recover P from waste streams (Cusick and Logan, 2012; Foroughi et al., 2019; Kappel et al., 2013; Lei et al., 2017; Wang et al., 2020). Compared to conventional methods for $\mathrm{P}$ recovery, including chemical phosphate removal (CPR), adsorption, and EBPR, EMP possesses the merits of simple operation. Moreover, chemical additions are not required in EMP because electrochemical reactions can lead to a high $\mathrm{pH}$ environment near the cathode to induce P deposition (Lei et al., 2017; Takabe et al., 2020). More importantly, EMP recovers bioavailable P in one process and requires no or little post-treatment. Therefore, EMP may help establish and maintain a new and sustainable $P$ cycle by utilizing the $P$ accumulated in waste streams as an alternative for mined $P$ rocks.

Several review articles have illustrated the application of ETs in wastewater treatment, including $\mathrm{P}$ removal by traditional electrochemical process (i.e., electrocoagulation) (Feng et al., 2016; Guedes et al., 2014; Li et al., 2020; Liu et al., 2020b; Muddemann et al., 2019; Nancharaiah et al., 2016; Perera et al., 2019; Tabassum et al., 2021). EMP is different from electrochemical coagulation. The latter process applies sacrificial electrodes to release cations (i.e., $\mathrm{Fe}^{2+}, \mathrm{Mg}^{2+}$ ) to remove phosphate, which would produce a large amount of sludge, and the electrodes need to be replaced regularly during long-term operation. By contrast, condensed $\mathrm{P}$ minerals would be produced in EMP process and the solids can be directly collected from the cathode surface. Besides, EMP usually employs inert electrodes, which are not consumed during the reaction. Other ETs, such as electrodialysis, often only concentrate $P$ in the wastewater. Therefore, a post-treatment is required for electrodialysis concentrate to remove $\mathrm{P}$ from the solution and recover $\mathrm{P}$ as an applicable product (Zhang et al., 2013). In comparison, EMP achieves $P$ removal and recovery in one system with one step and without dosing chemicals. However, to the best of our knowledge, there is no review article focusing on $\mathrm{P}$ removal and recovery using EMP. Therefore, this review article aims to fill in this knowledge gap by providing an overview of EMP developments for $\mathrm{P}$ removal and recovery.

First, we critically reviewed the mechanisms and influencing factors of EMP in P removal and recovery. Second, we emphasized the potential of EMP in treating non-ortho P compounds. Next, we evaluated the economic feasibility of EMP in recovering $P$ from the perspective of electricity consumption. Finally, we discussed the potential challenges toward the commercialization of EMP in P removal and recovery from wastewaters and proposed possible directions for future research.

\section{The working principle of electrochemically mediated precipitation}

A typical electrochemical system consists of an anode, a cathode, and an external power supply, as presented in Fig. 2A. EMP of P minerals is achieved through $\mathrm{pH}$ elevation at the cathode surface, while phosphate ions do not directly participate in the electrochemical reactions. At the cathode, water molecules are reduced into $\mathrm{H}_{2}$ and $\mathrm{OH}^{-}$, leading to the elevation of local pH (Eq. (1)). Meanwhile, cations (i.e., $\mathrm{Ca}^{2+}$ ) would move towards and accumulate near the cathode due to electric migration. As a result, the saturation index (SI) of P minerals would increase, driving the formation and precipitation of $\mathrm{P}$ minerals on the cathode, as shown in Eq. (2). Fig. 2B presents the SI of possible calcium phosphate (Ca-P) in response to the rise of local $\mathrm{pH}$. It is apparent that the rise of local $\mathrm{pH}$ increases the SI. Moreover, the high local $\mathrm{pH}$ near the cathode would reduce the solubility of $\mathrm{P}$ minerals (i.e., Ca-P), further boosting the precipitation of $\mathrm{P}$ minerals. In this way, the precipitates can be directly collected from the cathode, requiring no extra solid-liquid separation process, which is required in conventional methods.

At the anode, oxidation of water generates $\mathrm{H}^{+}$, neutralizing the $\mathrm{OH}^{-}$ produced on the cathode (Eq. (3)). Therefore, while the local pH at the cathode would increase, the bulk solution $\mathrm{pH}$ is not expected to change significantly in the electrochemical systems. Moreover, the presence of buffer ions, such as (bi)carbonate, would also stabilize the $\mathrm{pH}$ of the bulk solution (Cid et al., 2018; Lei et al., 2018b). Besides, the organic compounds in the solution would be oxidized and even mineralized to some extent at the anode.

Cathode: $4 \mathrm{H}_{2} \mathrm{O}+4 \mathrm{e}^{-} \rightarrow 4 \mathrm{OH}^{-}+2 \mathrm{H}_{2} \uparrow$

$5 \mathrm{Ca}^{2+}+3 \mathrm{HPO}_{4}{ }^{2-}+4 \mathrm{OH}^{-} \rightarrow \mathrm{Ca}_{5}\left(\mathrm{PO}_{4}\right)_{3} \mathrm{OH} \downarrow+3 \mathrm{H}_{2} \mathrm{O}$

Anode: $2 \mathrm{H}_{2} \mathrm{O} \rightarrow 4 \mathrm{H}^{+}+\mathrm{O}_{2} \uparrow+4 \mathrm{e}^{-}$

Struvite $\left(\mathrm{MgNH}_{4} \mathrm{PO}_{4} \bullet 6 \mathrm{H}_{2} \mathrm{O}\right)$ and Ca-P are the two common products in EMP system. The struvite process possesses the advantage of simultaneously recovering nitrogen $(\mathrm{N})$ and $\mathrm{P}$ (Karunanithi et al., 2015). Electrochemical struvite recovery has been studied for different waste streams (Huang et al., 2016; Hug and Udert 2013; Wang et al., 2010;
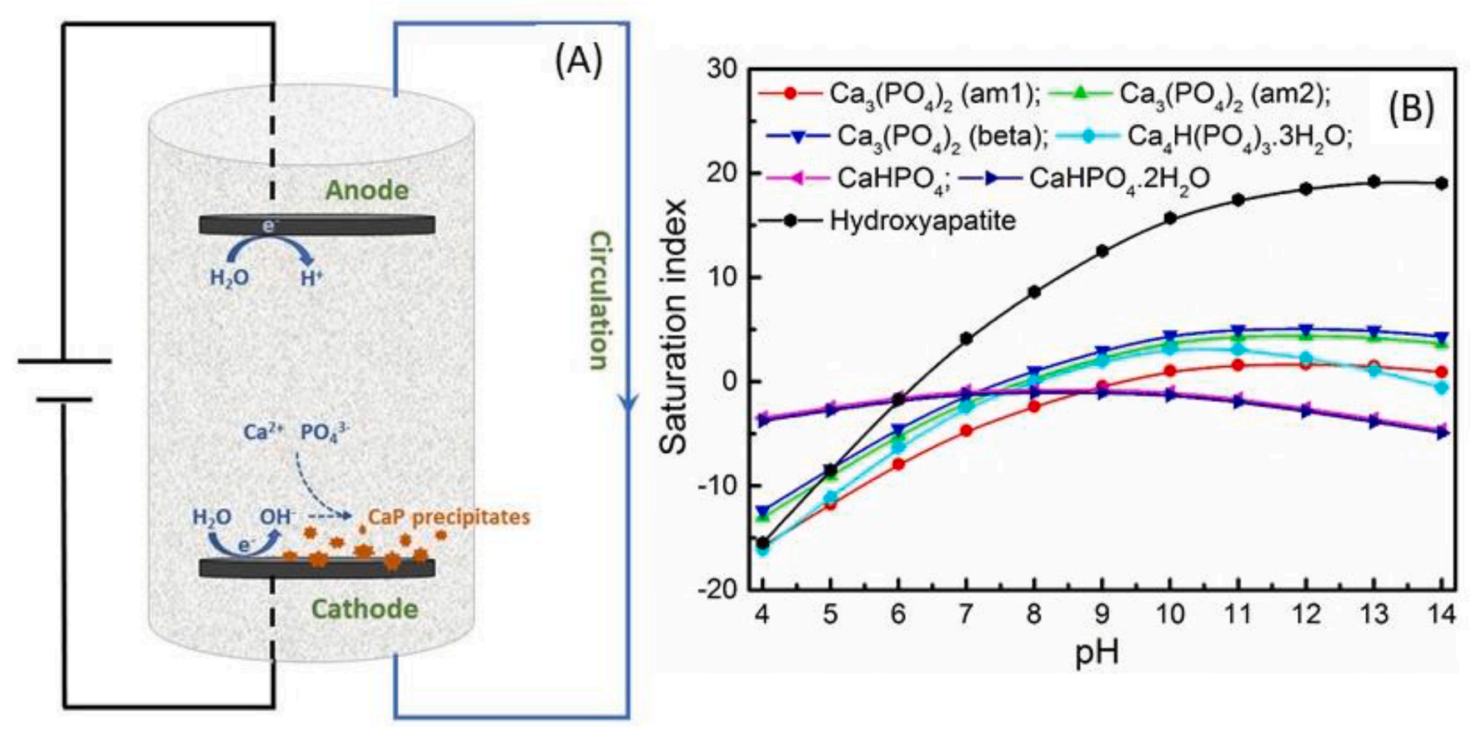

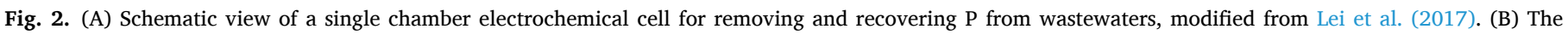

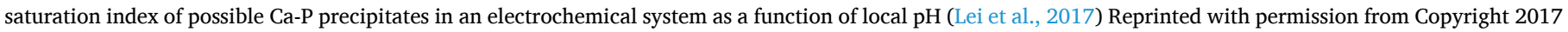
American Chemical Society. 
Zhang et al., 2019c). However, the direct formation of struvite at the cathode is challenging because the high local $\mathrm{pH}$ would favor the shift of $\mathrm{N}$ species from $\mathrm{NH}_{4}^{+}$to $\mathrm{NH}_{3}$ (Belarbi et al., 2020; Li et al., 2021b). Besides, a high $\mathrm{pH}$ environment may lead to the formation of $\mathrm{Mg}(\mathrm{OH})_{2}$ instead of struvite. Therefore, the current density, which regulates the production of $\mathrm{OH}^{-}$, needs to be controlled. Wang et al. (2022) reported that the percentage of struvite that deposits on the cathode decreased from $91 \%$ to $18 \%$ when the current density is increased from 5.8 to 17.3 $\mathrm{A} / \mathrm{m}^{2}$. Moreover, extra $\mathrm{Mg}^{2+}$ is usually required to achieve efficient struvite recovery. When targeted wastewater is low in $\mathrm{N}$ and $\mathrm{Mg}^{2+}$ content, it is more suitable to recover P as Ca-P (Eq. (2)) (Shaddel et al., 2019). $\mathrm{As} \mathrm{Ca}^{2+}$ widely exists in wastewater (typically $20-120 \mathrm{mg} / \mathrm{L}$ in domestic wastewater), there is no requirement for $\mathrm{Ca}^{2+}$ dosing in EMP of Ca-P, especially in calcium-enriched wastewaters, such as effluent from dairy industries (around $2200 \mathrm{mg} / \mathrm{L} \mathrm{Ca}^{2+}$ ) (Lei et al., 2018a; Lei et al., 2021a). Moreover, Ca-P recovered by EMP is similar in composition to rock phosphate and, therefore, a suitable alternative $\mathrm{P}$ source for industrial P fertilizer production without process modifications (Melia et al., 2017). In some EMP systems, ion exchange membranes (IEMs) are applied to prevent the neutralization of the anolyte (low pH) with the catholyte (high pH) (Kappel et al., 2013; Perera et al., 2020). With IEMs, the $\mathrm{P}$ recovery efficiency is projected to increase because the $\mathrm{pH}$ change in the media expands further away from the electrodes. Meanwhile, the low $\mathrm{pH}$ environment in the anode chamber can eliminate (bi)carbonate, which can significantly improve the purity of recovered solids (Lei et al., 2019b).

\subsection{The role of $p H$}

The $\mathrm{pH}$ is a decisive factor that affects the precipitation of $\mathrm{P}$ minerals. To differentiate, we will discuss local $\mathrm{pH}$, which is the $\mathrm{pH}$ at the cathode surface, and bulk $\mathrm{pH}$, which is the solution $\mathrm{pH}$ in general, in this section. Phosphate presents in various forms under different $\mathrm{pH}$ conditions, as shown in Fig. 3A. For example, $\mathrm{H}_{2} \mathrm{PO}_{4}{ }^{-}$is the main form when $\mathrm{pH}$ is below 7.2, while $\mathrm{HPO}_{4}{ }^{2-}$ becomes the predominating form when $\mathrm{pH}$ exceeds 7.2 ( $\$ \varnothing, 2011)$.

A high $\mathrm{pH}$ condition provides a higher thermodynamic driving force for phosphate to precipitate (Lei et al., 2017). Firstly, the SI of typical P precipitates (i.e., HAP) would elevate along with increasing $\mathrm{pH}$ value because phosphate would be deprotonated, and more $\mathrm{OH}^{-}$, the components of hydroxyapatite (HAP), would be available under high $\mathrm{pH}$. Secondly, the solubility of $\mathrm{P}$ precipitates is lower under high $\mathrm{pH}$ conditions, which benefits the deposition of P minerals. Lei et al. (2017) showed that $20 \%$ of $0.6 \mathrm{mM} \mathrm{P}$ was removed at an initial bulk pH of 10.0 even under open-circuit conditions in the presence of $1.0 \mathrm{mM} \mathrm{Ca}$, while no apparent $\mathrm{P}$ removal was observed at bulk $\mathrm{pH} 4.0$ or 8.4 .

However, in the electrochemical system, the bulk pH is less critical than local $\mathrm{pH}$ because the reduction of water molecules at the cathode raises the local $\mathrm{pH}$ and promotes the nucleation and growth of $\mathrm{P}$ crystals. In the same experimental setup but a closed electrical circuit $\left(3.8 \mathrm{~A} / \mathrm{m}^{2}\right)$, the $\mathrm{P}$ removal increased to over $48 \%$ in all three bulk pH conditions (4.0, 8.4, and 10.0) (Lei et al., 2017). Other studies also supported the argument that bulk pH is not crucial in EMP. Lu et al. (2005) deliberately controlled the bulk pH at 5.1 where Ca-P cannot be formed, but Ca-P was collected from the cathode. Furthermore, Ca-P was successfully recovered in an electrochemical system treating acidic cheese wastewater (bulk pH< 5) (Lei et al., 2021a). Lei et al. (2019b) also investigated EMP of $\mathrm{P}$ minerals in domestic wastewater as a function of acidification. They found that even with a dramatic change of bulk $\mathrm{pH}$ from 7.5 to 3.8 , the $\mathrm{P}$ removal efficiency was not much affected, decreased slightly from $55 \%$ to $49 \%$. Compared with the bulk $\mathrm{pH}$, the local $\mathrm{pH}$ is more affecting the electrochemical precipitation. According to Lei et al. (2017), the local $\mathrm{pH}$ near the cathode surface can reach as high as 13.2, significantly higher than the bulk pH. Nonetheless, the bulk pH still plays a role. It could indirectly affect $\mathrm{P}$ precipitation by influencing the speciation and even the (bi)carbonate concentration in wastewater. If the wastewater is acidified (low $\mathrm{pH}$ ), the (bi)carbonate concentration will decrease, which means less carbonate will compete for $\mathrm{Ca}^{2+}$ with phosphate. In this way, wastewater with low bulk pH could mitigate the adverse effect of (bi) carbonate on $\mathrm{P}$ precipitation.

The bulk pH is expected to remain stable in EMP process, attributing to the buffering ions in water and the neutralization of $\mathrm{H}^{+}$generated on the anode with $\mathrm{OH}^{-}$generated on the cathode (Perera et al., 2020). However, Lei et al. (2017) reported a severe decrease in bulk pH in EMP of Ca-P with synthetical solutions. This is because $\mathrm{OH}^{-}$produced at the cathode is consumed by precipitation reactions while there are no extra $\mathrm{H}^{+}$-consuming reactions in the system. Also, precipitation reactions remove buffer species from the water. At high current densities $\left(\mathrm{A} / \mathrm{m}^{2}\right)$, the generated $\mathrm{H}^{+}$exceeded the buffer capacity of the bulk solution, resulting in a decrease of the bulk pH (Perera et al., 2020). Lei et al. (2019b) showed that the change of bulk pH is linked to the initial bulk $\mathrm{pH}$ of treated domestic wastewater. The bulk $\mathrm{pH}$ of wastewater decreased after treatment when the initial bulk $\mathrm{pH}$ was acidified below 6.0, while it increased when the initial bulk $\mathrm{pH}$ was above 6.0. This is likely related to the loss of (bi)carbonate (buffer ions) by pre-acidification and the depletion of $\mathrm{OH}^{-}$by $\mathrm{CO}_{2}, \mathrm{Mg}^{2+}$, and $\mathrm{NH}_{4}^{+}$. Notably, it was also reported that the bulk $\mathrm{pH}$ increased after electrochemical treatment with the presence of (bi)carbonate, which would consume the $\mathrm{H}^{+}$generated on the anode and left the $\mathrm{OH}^{-}$accumulated in the bulk solution (Lei et al., 2019b; Lei et al., 2018b).

\subsection{Impact of current density}

In electrochemical systems, the applied current density directly determines the formation rate of $\mathrm{OH}^{-}$at the cathode, regulating the precipitation of $\mathrm{P}$ minerals. The $\mathrm{P}$ removal percentage increases with elevating current density because high current density would promote $\mathrm{OH}^{-}$production at the cathode, aiding $\mathrm{P}$ precipitation, as shown in Fig. 4A (Lei et al., 2019b; Lei et al., 2021a; Lei et al., 2021b; Perera et al., 2020; Takabe et al., 2020; Zhang et al., 2021). However, when the
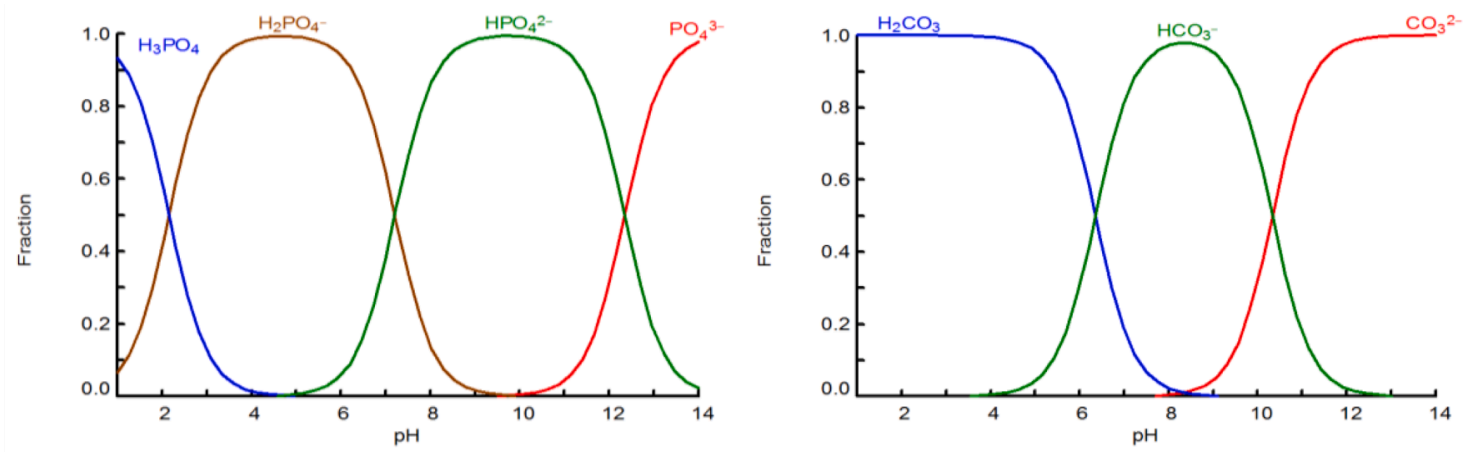

Fig. 3. The change of phosphate and carbonate speciation as a function of $\mathrm{pH}$ condition. 


\section{(A)}
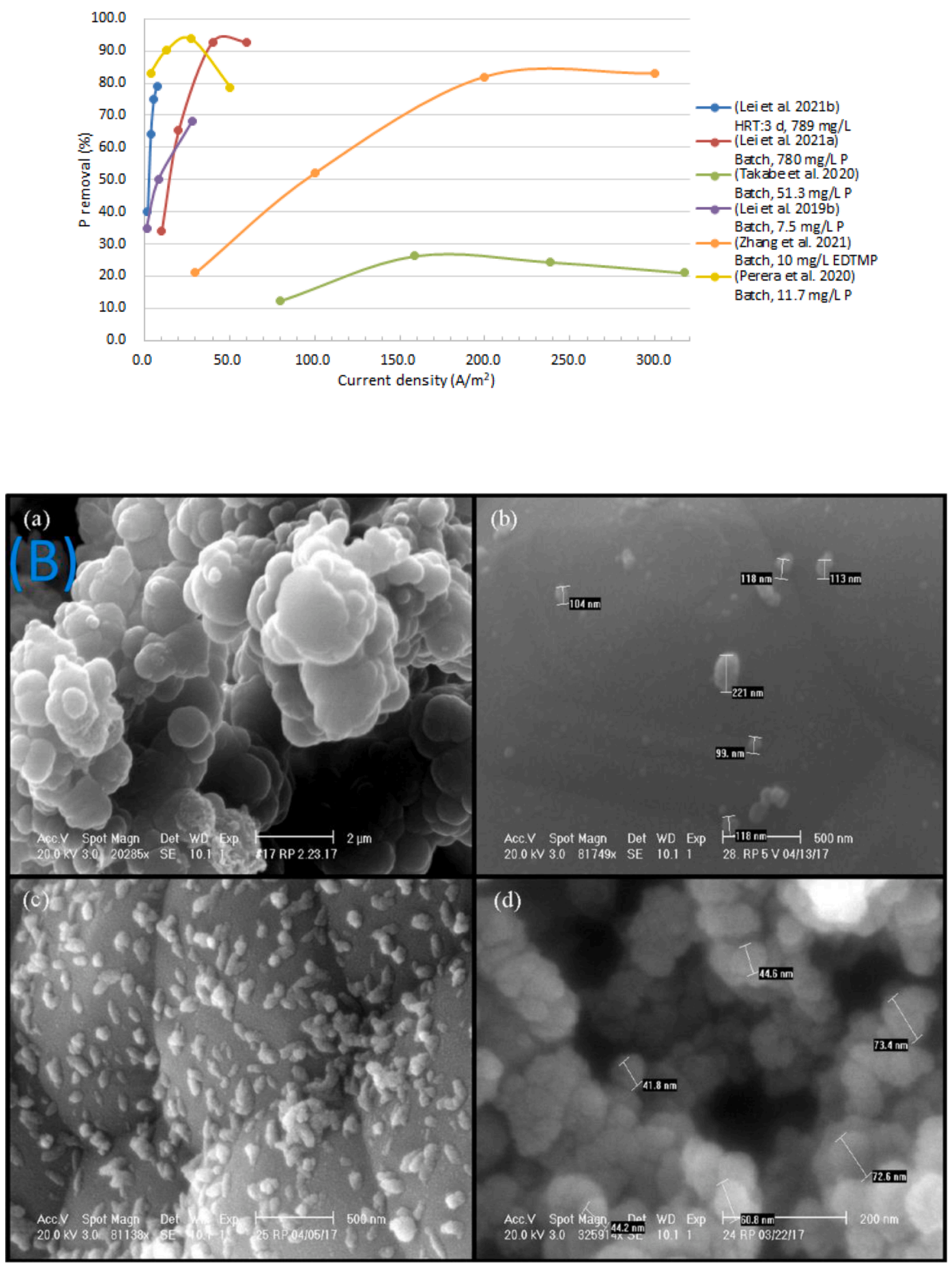

Fig. 4. (A) Change of $P$ removal with current density. (B) The Ca-P precipitates recovered at different current density: (a) $3.8 \mathrm{~A} / \mathrm{m}^{2}$, (b) $13.1 \mathrm{~A} / \mathrm{m}^{2}$, (c) $27.6 \mathrm{~A} / \mathrm{m}^{2}$, (d) $50.4 \mathrm{~A} / \mathrm{m}^{2}$ (Batch operation, $11.7 \mathrm{mg} / \mathrm{L} \mathrm{P}$ ) (Perera et al., 2020) Reprinted with permission from Copyright 2020 Elsevier.

current density exceeds a certain value, the $P$ removal percentage would maintain stable, as in the case of Lei et al. (2021a) and Zhang et al. (2021). The reason could be that there was too little P in the solution to be deposited as the $\mathrm{P}$ removal percentage was over $90 \%$ after the current density reached $40 \mathrm{~A} / \mathrm{cm}^{2}$. Another reason could be that the precipitation layer formed on the cathode hindered the $\mathrm{P}$ diffusion towards the cathode surface.

Interestingly, a porous structure (Fig. 6C), which is created by $\mathrm{H}_{2}$ generated on the cathode, was observed on the precipitation layer, and may assist $\mathrm{P}$ diffusion towards the cathode surface. In the study of Takabe et al. (2020), the P removal percentage slightly decreased after the current density surpassed a certain level (Fig. 4A). The limiting 
factor was the strong electrostatic repulsion between the cathode and phosphate at a very high current density. Moreover, the ortho P removal in the study of Takabe et al. (2020) was significantly lower than the other studies, indicating high current density (over $80 \mathrm{~A} / \mathrm{m}^{2}$ ) could hinder the precipitation of $\mathrm{P}$ minerals. Therefore, a low current density condition is favored during $P$ recovery for both $P$ removal and energy consumption. Additionally, the initial $\mathrm{P}$ removal rate would be affected by the applied current density. Cid et al. (2018) found that the P removal rate was increased from 0.05 to $0.13 \mathrm{mg} /(\mathrm{L} \bullet \mathrm{s})$ when the current density was increased from 26 to $150 \mathrm{~A} / \mathrm{m}^{2}$ (batch operation, $18.6 \mathrm{mg} / \mathrm{L} \mathrm{P}$ ).

The applied current density could also affect the size and composition of precipitates. Perera et al. (2020) found the size of precipitated particles decreased with increasing current density from 3.8 to 50.4 $\mathrm{A} / \mathrm{m}^{2}$, as presented in Fig. 4B. This is explained by the increased $\mathrm{pH}$ and SI of $\mathrm{P}$ minerals with increased current density, which results in preferred nucleation over growth for the crystallization process (Lu et al., 2005; Nielsen, 1969). However, small size precipitate would hinder the separation process and lead to low $\mathrm{P}$ recovery, as shown in Fig. 4A, supporting the argument that a low current density condition favors the P recovery. Moreover, Lei et al. (2018b) observed that amorphous calcium phosphate (ACP) was formed under $1.9 \mathrm{~A} / \mathrm{m}^{2}$ while HAP was found under $18.9 \mathrm{~A} / \mathrm{m}^{2}$ (batch operation, $18.6 \mathrm{mg} / \mathrm{L} \mathrm{P}$ ). Unfortunately, the relative abundance (RA) of Ca-P in recovered solids decreased with the increasing current density. When electrochemical $\mathrm{P}$ recovery was performed at a low current density of $0.2 \mathrm{~A} / \mathrm{m}^{2}$, almost none $\mathrm{Mg}(\mathrm{OH})_{2}$ and only limited $\mathrm{CaCO}_{3}$ were formed. Lei et al. (2020a) reported that a current density as low as $0.04 \mathrm{~A} / \mathrm{m}^{2}$ could trigger Ca-P precipitation at the cathode. Therefore, from the perspective of both removal efficiency and product purity, a very high current density is not desirable. Although with high current density, the removal kinetics can be enhanced, and the treatment time can be shortened, the purity of recovered products regarding $P$ content may be reduced, and the specific energy consumption may be increased.

\subsection{Impact of cell configuration}

\subsubsection{Exploration of bioanode}

In abiotic electrochemical systems, $\mathrm{P}$ precipitation is driven by external current, which generally results in high energy consumption. To reduce energy consumption, bioanodes could be applied. In a typical bioelectrochemical system (BES), exoelectrogenic microbes grow as firm biofilms on the anode, which oxidize soluble organic compounds in the bulk solution and release electrons to the anode (Logan et al., 2008; Logan et al., 2006). Thus, organic compounds act as electron donors in the BES instead of water as in abiotic electrochemical systems. The electrons are then transferred to the cathode through an external circuit to support the reduction reactions. At the cathode, either oxygen is reduced to water (oxygen reduction reaction, ORR) in a Microbial Fuel Cell (MFC), or $\mathrm{H}^{+}$/water are reduced to $\mathrm{H}_{2}$ gas (hydrogen evolution reaction, HER) in a Microbial Electrolysis Cell (MEC), elevating the local pH (Cusick et al., 2010). Fig. 5A is an example of a single chamber bioelectrochemical reactor. An external power supply is required to drive the nonspontaneous reactions (i.e., HER) at the cathode. The energy demand for bioelectrochemical mediated $\mathrm{P}$ precipitation was significantly reduced compared to that of abiotic electrochemical precipitation (Ichihashi and Hirooka, 2012; Yuan and Kim, 2017). Moreover, BES can effectively avoid the formation of chlorinated organic compounds, which are highly toxic to living organisms (Lei et al., 2019a).

Researchers have explored the possibility of BES in recovering P. Fischer et al. (2011) demonstrated that MFC could enable P recovery from digested sewage sludge. However, in their concept, the MFC was only used to dissolve and release phosphate from iron phosphate. Extra chemicals (magnesium and ammonium salts) and additional $\mathrm{pH}$ adjustments were still required to achieve P recovery eventually. Later, Ichihashi and Hirooka (2012) and Hirooka and Ichihashi (2013) investigated the potential of a single chamber air-cathode MFC on P removal and recovery. In the study of Ichihashi and Hirooka (2012), swine wastewater was flowing through two MFCs in a fed-batch mode. The results suggested that around $70-82 \% \mathrm{P}$ was removed in each MFC. In the study of Hirooka and Ichihashi (2013), P in artificial wastewater was removed at the range of $19-55 \%$ as struvite, depending on the concentrations of lattice ions $\left(\mathrm{Mg}^{2+}\right.$ and $\left.\mathrm{NH}_{4}^{+}\right)$. The two studies proved the achievability of $\mathrm{P}$ removal and recovery in BES. In MEC, the P removal effectiveness and the $P$ precipitation rate increased with current density (Blatter et al., 2019; Cusick and Logan, 2012; Lei et al., 2019a; Wang et al., 2019; Wang et al., 2020). Pepè Sciarria et al. (2019) compared the $P$ recovery effectiveness in a digestate by MEC and MFC, respectively. It was observed that MFC resulted in 10-15\% higher removal of $P$ than MEC (a fixed voltage of $1.07 \mathrm{~V}$ was applied).

In typical domestic wastewater, the amount of readily biodegradable organic carbon is inadequate for microbes to provide sufficient electric

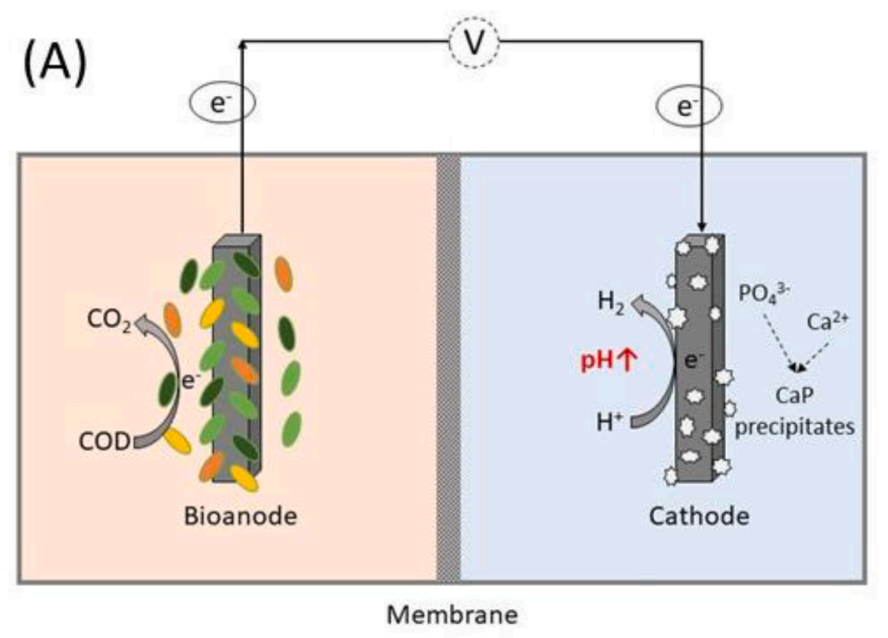

(B)

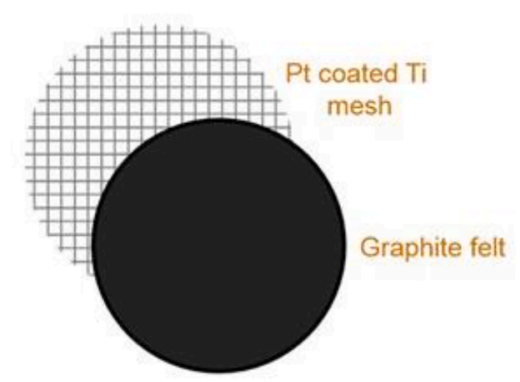

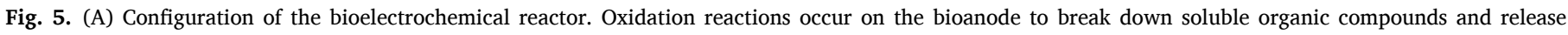

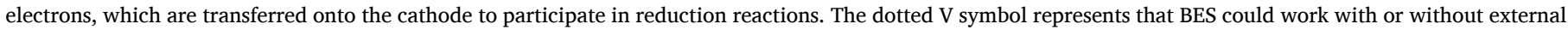

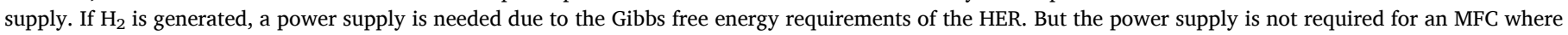

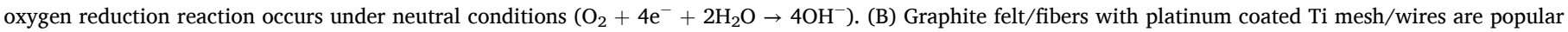
bioanode materials (Lei et al., 2019a). Reprinted with permission from Copyright 2019 American Chemical Society (CC-BY-NC-ND license). 
current and a high enough Coulombic Efficiency for a complete P recovery (Yuan and Kim, 2017). Therefore, supplementary organic compounds are usually spiked in bioelectrochemical reactors when treating actual wastewater (Cusick and Logan, 2012; Hirooka and Ichihashi, 2013). The P recovery would increase with elevating organic compounds (Almatouq and Babatunde, 2016; Lei et al., 2019a). However, adding organic compounds is a challenge for application because it increases the overall cost substantially and could cause unexpected interactions in the water matrix.

Membranes are used in (bio)electrochemical systems to separate the anodic and the cathodic chamber, which could effectively improve P removal effectiveness (Fischer et al., 2011; Tao et al., 2014). Ye et al. (2019a) obtained a P recovery from $24.4 \%$ to $83.2 \%$ in a CEM-contained MEC. Similarly, Wang et al. (2020) applied three types of membranes (bipolar membrane, AEM, and CEM) in a MEC and recovered over 80\% of $\mathrm{P}(5 \mathrm{mM})$ in the form of Ca-P. Notably, Ye et al. (2019b) tested three types of membranes (CEM, forward osmosis membrane, and nonwoven membrane) and found that MFC with CEM had the best $P$ removal effectiveness (95\%). However, the use of membranes could trigger problems, such as membrane fouling and high internal resistance of the reactor, which could lower energy efficiency and increase the cost (Blatter et al., 2020; Cusick et al., 2014; Happe et al., 2016; Kumar et al., 2019; Marassi et al., 2020).

\subsubsection{Design of cathode}

In membrane-less EMP, the cathode is where the precipitation of $\mathrm{P}$ minerals occurs. Therefore, the cathode design plays an important role in the removal and recovery of P. Firstly, the surface area of the cathode would affect $\mathrm{P}$ removal efficiency as well as the purity of the recovered product. Cusick and Logan (2012) reported that the P recovery as struvite with stainless-steel mesh (SSM, $19 \mathrm{~cm}^{2}$ ) and stainless-steel foil (SSF, $7 \mathrm{~cm}^{2}$ ) was similar when the applied voltage ranged from 0.75 to $0.90 \mathrm{~V}$. In this voltage range, the output current may be the limiting factor instead of the electrode area. However, when the voltage was increased from 0.90 to $1.05 \mathrm{~V}$, SSM gave higher P recovery (40\%) than SSF (26\%) due to its larger surface area. In contrast, Yuan and Kim (2017) argued that SSF would perform better when there was a large amount of $\mathrm{P}$ to recover. They tested the performance of single SSM, multiple SSM, and SSF as the cathode in MEC and found that the P recovery was lower with SSM cathode, although the P removal was not affected. The possible reason is that the size of struvite crystals was too small to be collected from the open spaces in SSM. Besides, Lei et al. (2018a) tested titanium plate cathode with three different surface areas $\left(4,16\right.$, and $36 \mathrm{~cm}^{2}$ ) under the same current supply. They observed that the formation of Ca-P significantly increased with the cathode area. A larger surface area favors the formation of Ca-P because the generation of both $\mathrm{Mg}(\mathrm{OH})_{2}$ and $\mathrm{CaCO}_{3}$ can be limited under low current density (Lei et al., 2020a). Notably, when a large specific surface area is required, carbon-based materials (i.e., graphite felt) are better alternatives than traditional titanium plates (Lei et al., 2020a). Fig. 6 shows the images of the precipitation of $\mathrm{P}$ minerals on different types of cathode.

Apart from the surface area and the material, the gap between electrodes also matters. Lei et al. (2019d) studied P removal at different anode and cathode distances $(0.5,3.0$, and $6.0 \mathrm{~cm})$. While the P removal efficiency was not affected by the anode and cathode distance under a constant current mode, a smaller gap could significantly reduce the cell potential (from $4.6 \mathrm{~V}$ to $3.4 \mathrm{~V}$ ), so as the energy consumption. Besides, Li et al. (2021a) stated that cell potential plays a more important role in $P$ recovery than electrode distance. Moreover, the electrode gap would influence the recombination of cathode-produced $\mathrm{OH}^{-}$with anode-produced $\mathrm{H}^{+}$, affecting the utilization rate of $\mathrm{OH}^{-}$for precipitation. Lei et al. (2019c) proposed a simple yet efficient way to deal with the acid-base neutralization issue in electrochemical systems by introducing $\mathrm{CaCO}_{3}$ particles into the electrochemical cell to fill up the space between the anode and the cathode, as presented in Fig. 7A (Lei et al., 2019c). When $\mathrm{H}^{+}$is produced at the anode, it would firstly react with
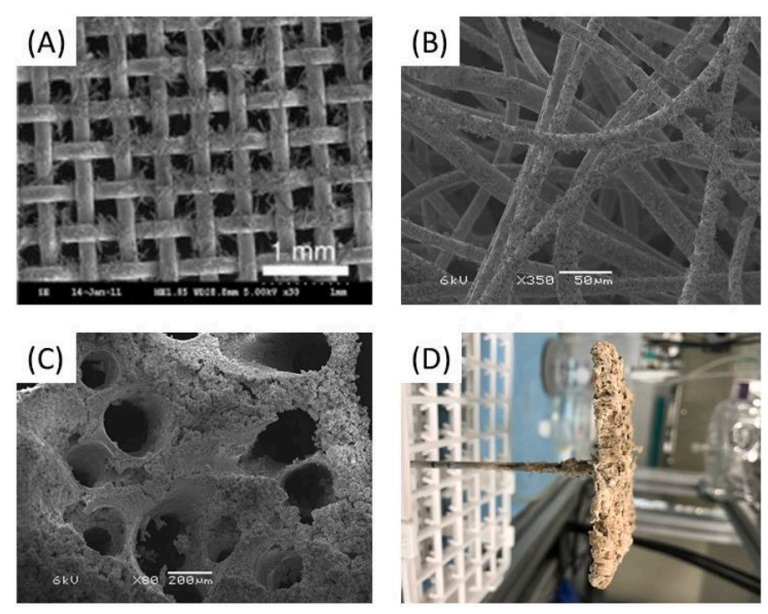

Fig. 6. (A) SEM image of struvite crystal growth on SSM (Cusick and Logan 2012). (B) SEM image of Ca-P growth on graphite (Lei et al., 2020a). (C) SEM image of holes in Ca-P precipitates created by $\mathrm{H}_{2}$; (D) Real images of dried precipitates at $\mathrm{Ti}$ cathode (Lei et al., 2019d). Reprinted with permission from Copyright 2011 Elsevier, Copyright 2019 Elsevier, and Copyright 2019 American Chemical Society.

$\mathrm{CaCO}_{3}$ instead of neutralizing with $\mathrm{OH}^{-}$, leading to an accumulation of $\mathrm{OH}^{-}$even in the bulk solution and releasing $\mathrm{Ca}^{2+}$ for the precipitation of Ca-P (Eq. (4)). Consequently, Ca-P would precipitate on the cathode, and on the surface of $\mathrm{CaCO}_{3}$ particles, and even in the solution. Similarly, siderite $\left(\mathrm{FeCO}_{3}\right)$, magnesite $\left(\mathrm{MgCO}_{3}\right)$, and dolomite $\left(\mathrm{CaMg}\left(\mathrm{CO}_{3}\right)_{2}\right)$ were packed in the electrochemical cell to assist the precipitation of ferric phosphate, struvite, and other P-containing products, respectively (Chen et al., 2021; Li et al., 2021a; Li et al., 2021b).

$\mathrm{CaCO}_{3}+2 \mathrm{H}^{+} \rightarrow \mathrm{Ca}^{2+}+\mathrm{CO}_{2} \uparrow+\mathrm{H}_{2} \mathrm{O}$

Automatic product collection could be achieved through intelligent cathode design. $\mathrm{P}$ precipitates could be redissolved and detached from the cathode by temporarily reversing the polarity of the platinized titanium anode and cathode (Perera et al., 2020; Takabe et al., 2020). Perera et al. (2020) and Takabe et al. (2020) reported that 3 min polarity reversal was enough to detach the whole $P$ precipitates from the "new anode". The $\mathrm{H}^{+}$generated at the new anode (former cathode) would dissolve part of the precipitates and reduce the adhesion of crystals to the new anode. Besides, oxygen produced on the new anode may help the detachment and sedimentation of deposits. Other cell designs could also benefit the collection of precipitates. Varigala et al., 2021 adjusted the reactor into a hopper shape coupled with a suction pipe, collecting sediments without interrupting operation, as shown in Fig. 7C. Notably, Lei et al. (2021b) designed a scalable column-shaped electrochemical reactor that consists of a tubular stainless-steel cathode, as presented in Fig. 7B. Although the anode and cathode were placed vertically against each other, the precipitates did not fall off from the cathode surface over 173 days of continuous operation.

\subsection{Impact of water matrix}

Given the complexity of actual wastewater, it is crucial to test the performance of EMP system for P recovery in both synthetic solutions and real wastewater to understand the uncertainty of wastewater characteristics and eventually predict how the water matrix would affect $\mathrm{P}$ precipitation in the electrochemical system.

\subsubsection{Phosphate concentration}

The initial phosphate concentration in wastewater is crucial for applying EMP in recovering P (Lei et al., 2019d; Lei et al., 2020b; Lei et al., 2017; Zhang et al., 2021). Li et al. (2021a) and Chen et al. (2021) 

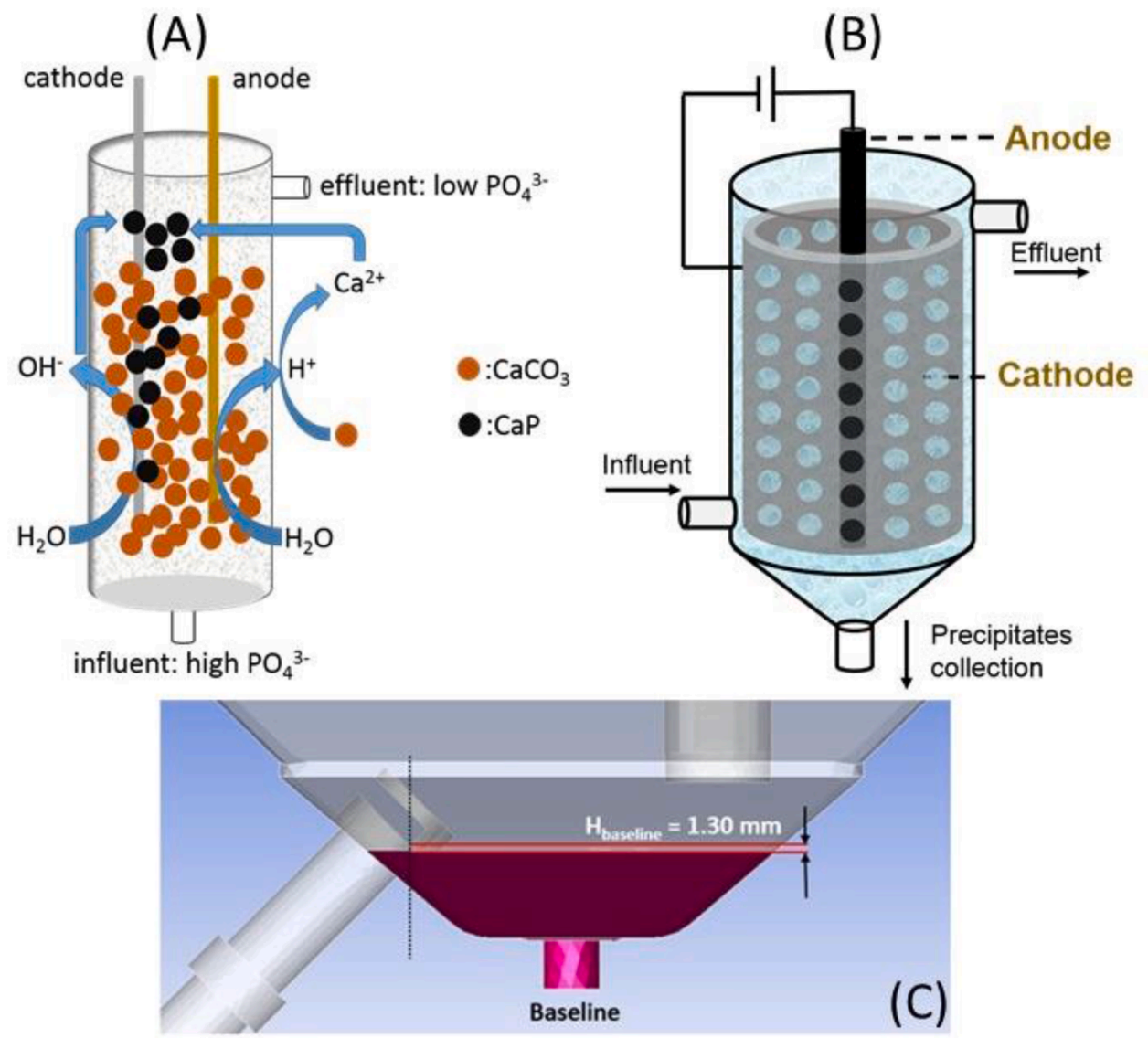

Fig. 7. (A) Mechanism of calcium carbonate packed electrochemical precipitation column (Lei et al., 2019c). (B) Diagram of scalable column-shaped electrochemical reactor with a tubular stainless-steel cathode (Lei et al., 2021b). (C) Design of hopper-shaped electrochemical reactor with a suction pipe (Varigala et al., 2021). Reprinted with permission from Copyright 2019 American Chemical Society, 2021 Elsevier, and 2020 Wiley Periodicals.

observed that the $\mathrm{P}$ recovery rate increased with initial $\mathrm{P}$ concentration. On the contrary, Yuan and Kim (2017) illustrated that P recovery dropped with increasing phosphate concentration, which may be related to the cathode structure (SSM) that cannot hold a large number of struvite crystals. From this perspective, a different cathode type should be used, or precipitates produced in the system should be collected regularly to maintain a high $P$ recovery. Wang et al. (2020) investigated P removal as a function of phosphate concentration (61.9 to 464.6 $\mathrm{mg} / \mathrm{L}$ ) in a MEC system. After 8 hours' reaction, they observed that $\mathrm{P}$ recovery exceeded $80 \%$ with $61.9 \mathrm{mg} / \mathrm{L}$ phosphate, while $\mathrm{P}$ recovery was around $50 \%$ with $154.9 \mathrm{mg} / \mathrm{L}$ phosphate and below $50 \%$ with 309.7 and $64.6 \mathrm{mg} / \mathrm{L}$ phosphate. It is worth mentioning that a high concentration of $\mathrm{H}_{2} \mathrm{PO}_{4}^{-}$may lower the local $\mathrm{pH}$ via its buffering capacity. Likewise, Lei et al. (2021b) reported that the P removal efficiency increased with dilution in electrochemical $\mathrm{P}$ recovery from cheese wastewater which has a P concentration as high as $789 \mathrm{mg} / \mathrm{L}$. However, the $\mathrm{P}$ removal rate decreased dramatically from 1194 to $207 \mathrm{mg}$ P/day.

\subsubsection{Interaction with coexisting substances}

The purity of recovered $\mathrm{P}$ minerals mostly depends on phosphate concentration. Lei et al. (2019a) demonstrated that an increase of phosphate concentration from 0.23 to $0.76 \mathrm{mM}$ results in increased RA of Ca-P from $21 \mathrm{wt} \%$ to $66 \mathrm{wt} \%$. However, in typical domestic wastewater, the (bi)carbonate concentration is significantly higher than phosphate. The (bi)carbonate concentration in wastewater would affect $\mathrm{P}$ removal efficiency and the quality of recovered $\mathrm{P}$ products. $\mathrm{CO}_{3}{ }^{2-}$ would compete for $\mathrm{Ca}^{2+}$ to form $\mathrm{CaCO}_{3}$ and carbonate-substituted HAP (Cid et al., 2018; Lei et al., 2017). Takabe et al. (2020) observed that about $34 \% \mathrm{Ca}^{2+}$ was removed in the form of $\mathrm{CaCO}_{3}$. Lei et al. (2018b) showed a reduced P removal from $51.9 \%$ to $24.6 \%$ when (bi)carbonate concentration was increased from 1.0 to $10.0 \mathrm{mM}$ (pH is around 8.0). However, if the (bi)carbonate concentration is low $(1.0$ or $3.0 \mathrm{mM})$, the $\mathrm{P}$ removal efficiency was promoted by $7.1 \%$ and $7.6 \%$, respectively. This is because a low (bi)carbonate concentration is beneficial to establish a high local $\mathrm{pH}$ environment near the cathode while not reducing free $\mathrm{Ca}^{2+}$ significantly. The (bi)carbonate speciation is highly $\mathrm{pH}$-dependent (Fig. 3). Therefore, the adverse influence of (bi)carbonate may be reduced by adjusting $\mathrm{pH}$. Lei et al. (2019b) showed that when adjusting wastewater $\mathrm{pH}$ from 7.5 to 3.8 , the calcium carbonate formation significantly decreased, but the P removal remained around $50 \%$.

Magnesium ( $\mathrm{Mg}$ ) in water can form multiple precipitates, such as brucite $\left(\mathrm{Mg}(\mathrm{OH})_{2}\right)$, dolomite, and struvite in the presence of ammonium and phosphate (Lei et al., 2019b; Takabe et al., 2020). In electrochemical systems, $\mathrm{Mg}^{2+}$ moves to the cathode due to mass diffusion and electromigration, forming $\mathrm{Mg}(\mathrm{OH})_{2}$, the governing magnesium species in the recovered precipitates (Lei et al., 2019b). Moreover, $\mathrm{Mg}^{2+}$ can substitute $\mathrm{Ca}^{2+}$, incorporating into Ca-P structure, or being adsorbed onto HAP crystals (Cao and Harris, 2008). Furthermore, the presence of $\mathrm{Mg}^{2+}$ may influence the growth rate and the solubility of HAP (Cid et al., 2018). Lowering the amount of $\mathrm{Mg}$ precipitates is possible through $\mathrm{pH}$ adjustment and current density control (Lei et al., 2019b).

Natural organic matter (NOM), such as humic acid and fulvic acid, is ubiquitous in water bodies and soil. Lei et al. (2018c) studied the influence of three types of NOM (Suwannee River NOM, Nordic Lake NOM, and Pony Lake NOM) on P removal during electrochemical treatment. Overall, NOM improved Ca-P precipitation on the cathode surface to some extent, mainly via physical co-precipitation with Ca-P after balancing its negative effect on free $\mathrm{Ca}^{2+}$ availability in the bulk 
solution. In addition, the studies of Kappel et al. (2013) and Lei et al. (2018c) indicated that NOM could slow down the formation of crystalline Ca-P. Lei et al. (2018c) also found that the co-precipitation of NOM with Ca-P alters the color of recovered solids. The color intensity increases with the increase of NOM concentration.

\section{Non-ortho phosphorus}

Next to ortho-phosphate, electrochemical systems can also remove and recover $\mathrm{P}$ from non-ortho $\mathrm{P}$ compounds, including phosphonates, organic phosphorus, and hypophosphite (Fig. 8). Non-ortho P is widely found in aquatic ecosystems as one of the leading $\mathrm{P}$ fractions (Brooker et al., 2018). In water bodies, non-ortho $P$ can be photochemically or microbiologically decomposed and transformed into more active ortho-phosphate, contributing to the eutrophication of water bodies (Zhang et al., 2019b). However, technologies mainly focus on the removal and recovery of ortho-phosphate. Only a few studies have investigated the potential of recovering $\mathrm{P}$ from non-ortho P. Biological processes, ozonation, advanced oxidation process, and ion exchange resins have been applied to remove and, to a less extent, recover $P$ from non-ortho P. Chemical processes have been developed to enhance the removal of non-ortho P. Pocostales et al. (2010) successfully degraded organic $\mathrm{P}$ with ozone. Besides, microwave-activated peroxide, generating hydroxyl radicals, was applied to convert organic $\mathrm{P}$ into ortho-phosphate, which can be concentrated and recovered through post-treatment (Gifford et al., 2015; Pocostales et al., 2010). In addition, UV technology has been developed to convert organic $\mathrm{P}$ into ortho-phosphate through either direct photolysis or indirect photodegradation by reactive oxygen species (Rott et al., 2017; Sindelar et al., 2016; Sun et al., 2019; Zhang et al., 2019b). Based on previous studies, it can be concluded that $\mathrm{P}$ recovery from non-ortho $\mathrm{P}$ compounds is a two-step process. Firstly, non-ortho $\mathrm{P}$ needs to be converted into ortho-phosphate, and then the converted ortho-phosphate is removed or recovered through approaches developed for ortho-phosphate.

Lei et al. (2020b) recovered Ca-P from synthetic wastewater loaded with organic P (Nitrilotris, see Fig. 8A) using a single cell electrochemical system with Pt anode and Ti cathode. As shown in Fig. 9A, organic $\mathrm{P}$ was converted to ortho-phosphate by anode or anode-mediated oxidation. Subsequently, the converted ortho-phosphate precipitated with calcium ions on the cathode surface, where a high $\mathrm{pH}$ environment was established by water reduction. Additionally, Lei et al. (2020b) found that the recovery performance was better in actual wastewater than in model solutions. This is because chloride ions in real waste streams result in the formation of reactive chlorine species (i.e., $\mathrm{ClO}^{-}$), which can facilitate the oxidization of organic P. Subsequently, Zhang et al. (2021) again proved the possibility of one-step P recovering from phosphonates (EDTMP, Fig. 8B) in an electrochemical cell with synthetic wastewater.

Furthermore, Marassi et al. (2020) investigated the continuous flow treatment of dairy wastewater in a $2.8 \mathrm{~L}$ air-cathode MFC. The MFC cell realized $90 \%$ removal of organic P. During the long-term operation period (105 days), the ortho-phosphate concentration increased initially in the effluent, indicating the transformation of organic $\mathrm{P}$ into ortho-phosphate which is likely due to microbial degradation (Nancharaiah et al., 2016). Later, the ortho-phosphate concentration decreased in the effluent, probably due to EMP of P minerals, as crystals were observed on the cathode surface.

Zhang et al. (2019a) designed a single-compartment photoelectrocatalytic cell (PEC) with $\mathrm{TiO}_{2} / \mathrm{Ni}-\mathrm{Sb}-\mathrm{SnO}_{2}$ (TNA/NSS) bifunctional photoanode and activated carbon fiber (ACF) cathode to treat hypophosphite-loaded (see Fig. 8C) wastewater. As illustrated in Fig. 9B, at the anode, photoelectrocatalytic reactions generate $\mathrm{Fe}^{3+}$ (from $\mathrm{Fe}^{2+}$ ), active oxidants (i.e., hydroxyl radical and ozone) and electrons. The active oxidants convert hypophosphite into ortho-phosphate, which would form insoluble iron phosphate with $\mathrm{Fe}^{3+}$. Moreover, $\mathrm{H}_{2} \mathrm{O}_{2}$ can be produced at the cathode, enhancing the oxidation of hypophosphite. In the tested PEC, $1.0 \mathrm{mM}$ hypophosphite was entirely oxidized at $3.0 \mathrm{~V}$ with $3.0 \mathrm{mM} \mathrm{Fe}{ }^{2+}$ addition (Zhang et al., 2019a). The authors assessed the efficiency and the economic aspect of the PEC system for treating hypophosphite enriched real electroless nickel plating effluents. They concluded that $\mathrm{P}$ could be effectively recovered in the form of $\mathrm{FePO}_{4}$ at a lower cost compared to the conventional Fenton process. Even though this system removes non-ortho $\mathrm{P}$ in a single-step treatment, the product cannot be used directly as fertilizer because of the low $\mathrm{P}$ bioavailability of iron phosphate.

Several factors affect the performance of EMP in removing and recovering non-ortho $P$. Firstly, the anode material determines the transformation effectiveness of non-ortho P into ortho-phosphate. Lei et al. (2020b) compared three types of anode materials and elucidated that the oxidation efficiencies are in the order of Ru-Ir $>$ Pt-Ir $>$ Pt. Similarly, TNA/NSS generate HO., a powerful oxidant near the anode, improving the evolution of ortho-phosphate (Zhang et al., 2019a). Secondly, coexisting ions and substances in wastewater affect the system efficiency. Lei et al. (2020b) elucidated that chloride ion has a positive effect on non-ortho $P$ conversion due to the formation of chlorine. In the photoelectrochemical system designed by Zhang et al. (2019b), nitrate and NOM enhanced non-ortho $\mathrm{P}$ removal because they are photo-sensitizers and could promote the formation of HO. In contrast, (bi)carbonate shows a negative impact because it scavenges HO. Lastly, the solution $\mathrm{pH}$ may influence the anodic reactions. A better P recovery was observed under acidic conditions because it is beneficial to HO. generation (Zhang et al., 2019a; Zhang et al., 2019b).

\section{Economic assessment}

Table 1 presents an economic comparison of different electrochemical systems towards $\mathrm{P}$ removal and recovery regarding specific electricity consumption. In theory, the electricity consumption of recovering ortho phosphate can be as low as $0.3 \$ / \mathrm{kg}$ in the electrochemical system while $0.22 \$ / \mathrm{kg}$ in the BES, assuming the electricity price is $0.1 \$ / \mathrm{kWh}$ (Kappel et al., 2013; Wang et al., 2020). If taking the cost of chemicals into consideration $\left(\mathrm{Ca}^{2+}\right.$ addition), the total cost of

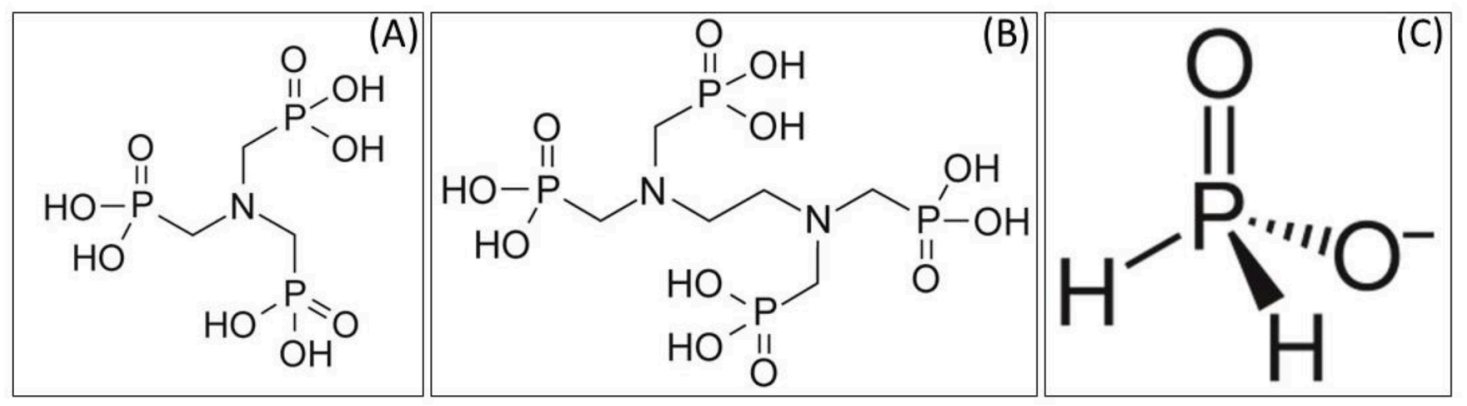

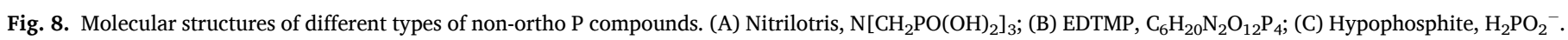




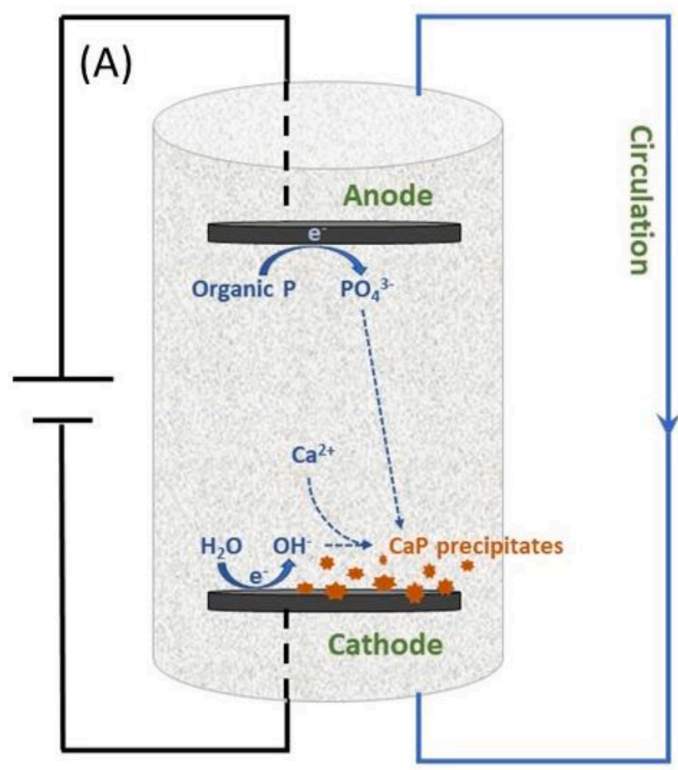

(B)

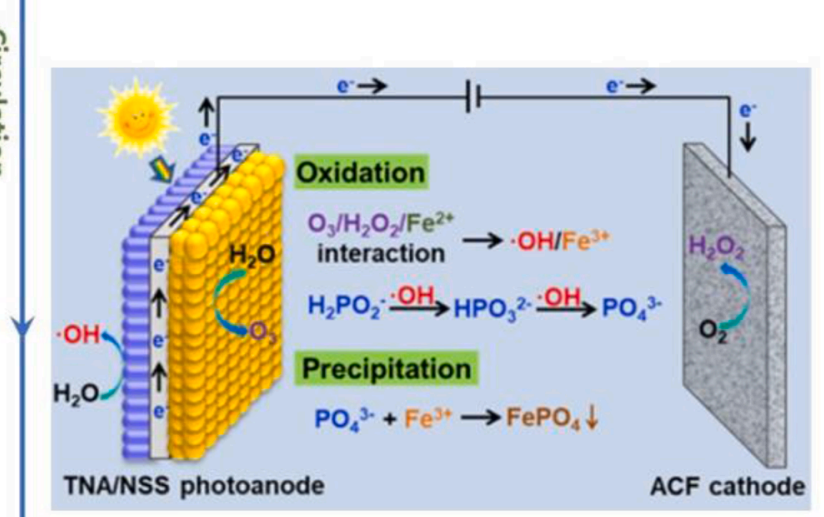

Fig. 9. (A) Principle of electrochemical P removal and recovery from non-ortho P compounds, modified from Lei et al. (2020b). (B) Demonstration of a single-compartment photoelectrocatalytic cell (PEC) (Zhang et al., 2019a). Reprinted with permission from Copyright 2019 American Chemical Society.

Table 1

The economic evaluation of P removal and recovery by EMP of P minerals under different operational conditions, cell configurations, and types of wastewaters (blue tables represent electrochemical systems, orange tables represent non-ortho $P$ treatment, and green tables represent BES).

\begin{tabular}{|c|c|c|c|c|c|c|c|}
\hline Type of wastewater & Description & $\begin{array}{l}\text { Current } \\
\text { density (A/ } \\
\mathrm{m}^{2} \text { ) }\end{array}$ & Product & $\begin{array}{l}\mathrm{P} \text { removal } \\
(\%)\end{array}$ & $\begin{array}{l}\text { Energy } \\
\text { consumption } \\
(\mathrm{kWh} / \mathrm{kg} \mathrm{P})\end{array}$ & Note & Reference \\
\hline $\begin{array}{l}\text { Cheese wastewater, } 789 \\
\text { mg/L ortho } P\end{array}$ & $\begin{array}{l}\text { Tubular-shaped stainless-steel } \\
\text { cathode }\end{array}$ & $1.9-7.5$ & Ca-P & $\begin{array}{l}40-79 \% \\
\text { HRT: } 36 \text { h }\end{array}$ & $27.0-65.2$ & Continuous & $\begin{array}{l}\text { (Lei et al., } \\
\text { 2021b) }\end{array}$ \\
\hline $\begin{array}{l}\text { Cheese wastewater, } 780 \\
\text { mg/L ortho } \mathrm{P}\end{array}$ & Pt-coated Ti cathode & 7.5 & Ca-P & $92.7 \%, 96 \mathrm{~h}$ & 64.7 & Batch & $\begin{array}{l}\text { (Lei et al., } \\
\text { 2021a) }\end{array}$ \\
\hline $\begin{array}{l}\text { Synthetic wastewater, } 62 \\
\text { mg/L ortho P }\end{array}$ & Ti cathode & 3.1 & Struvite & $\begin{array}{l}90 \%, \text { HRT: } \\
0.5 \mathrm{~h}\end{array}$ & 12.5 & $\begin{array}{l}\text { Continuous, } \\
\text { packed magnesite } \\
\text { particles }\end{array}$ & $\begin{array}{l}\text { (Li et al., } \\
\text { 2021a) }\end{array}$ \\
\hline $\begin{array}{l}\text { Synthetic wastewater, } 31 \\
\text { mg/L ortho P }\end{array}$ & Ti cathode & 3.1 & $\begin{array}{l}\text { P-N } \\
\text { precipitates }\end{array}$ & $93 \%, 0.5 \mathrm{~h}$ & 23.2 & $\begin{array}{l}\text { Continuous, } \\
\text { packed dolomite }\end{array}$ & $\begin{array}{l}\text { (Li et al., } \\
\text { 2021b) }\end{array}$ \\
\hline $\begin{array}{l}\text { Domestic wastewater, } 8.0 \\
\mathrm{mg} / \mathrm{L} \text { ortho } \mathrm{P}\end{array}$ & GF-Pt-Ti cathode & 0.2 & Ca-P & $70 \%, 96 \mathrm{~h}$ & 26.4 & Batch & $\begin{array}{l}\text { (Lei et al., } \\
\text { 2020a) }\end{array}$ \\
\hline $\begin{array}{l}\text { Synthetic wastewater, } 11.7 \\
\mathrm{mg} / \mathrm{L} \text { ortho } \mathrm{P}\end{array}$ & $\begin{array}{l}\text { A three-chamber } \\
\text { electrohydromodulation, graphite } \\
\text { plate cathode }\end{array}$ & $3.8-50.4$ & Ca-P & $\begin{array}{l}79-94 \% \\
0.5-6 \mathrm{~h}\end{array}$ & $63.4-202.5$ & Batch & $\begin{array}{l}\text { (Perera } \\
\text { et al., 2020) }\end{array}$ \\
\hline $\begin{array}{l}\text { Domestic wastewater, } 7.7 \\
\text { mg/L ortho P }\end{array}$ & Ti cathode & $1.4-27.8$ & Ca-P & $\begin{array}{l}44-72 \%, 24 \\
\text { h }\end{array}$ & $110-2238$ & Batch & $\begin{array}{l}\text { (Lei et al., } \\
\text { 2019d) }\end{array}$ \\
\hline $\begin{array}{l}\text { Synthetic wastewater, } 18.6 \\
\text { mg/L ortho P }\end{array}$ & Pt-Ti anode, Ti cathode & 3.5 & Ca-P & $\begin{array}{l}28-87 \% \\
\text { HRT: } \\
2.1-6.3 \mathrm{~h}\end{array}$ & $29-61$ & $\begin{array}{l}\text { Continuous, } \\
\text { packed } \mathrm{CaCO}_{3}\end{array}$ & $\begin{array}{l}\text { (Lei et al., } \\
\text { 2019c) }\end{array}$ \\
\hline $\begin{array}{l}\text { Toilet wastewater, } 18.6 \\
\text { mg/L ortho P }\end{array}$ & $\begin{array}{l}\text { Sequential batch reactor with } \\
\text { stainless steel cathode }\end{array}$ & 26 & Ca-P & $50 \%, 5 \mathrm{~h}$ & 4399 & Batch & $\begin{array}{l}\text { (Cid et al., } \\
\text { 2018) }\end{array}$ \\
\hline $\begin{array}{l}\text { Domestic wastewater, } 7.8 \\
\mathrm{mg} / \mathrm{L} \text { ortho } \mathrm{P}\end{array}$ & Ti cathode & 3.8 & Ca-P & $42.8 \%, 24 \mathrm{~h}$ & 457 & Batch & $\begin{array}{l}\text { (Lei et al., } \\
\text { 2017) }\end{array}$ \\
\hline $\begin{array}{l}\text { Nanofiltration concentrate, } \\
23 \mathrm{mg} / \mathrm{L} \text { ortho } \mathrm{P}\end{array}$ & Steel cathode & 4.6 & Ca-P & $70-95 \%, 1 \mathrm{~h}$ & $\begin{array}{l}3.0-12.6 \text { (in } \\
\text { theory) }\end{array}$ & Batch & $\begin{array}{l}\text { (Kappel } \\
\text { et al., 2013) }\end{array}$ \\
\hline $\begin{array}{l}\text { Cooling circulating water, } \\
8.6 \mathrm{mg} / \mathrm{L} \mathrm{TP}\end{array}$ & Ti cathode & 20 & Ca-P & $74 \%, 0.75 \mathrm{~h}$ & 2050 & Batch & $\begin{array}{l}\text { (Zhang } \\
\text { et al., 2021) }\end{array}$ \\
\hline $\begin{array}{l}\text { Electroless nickel plating } \\
\text { effluents, } 708 \mathrm{mg} / \mathrm{L} \\
\mathrm{H}_{2} \mathrm{PO}_{2}{ }^{-}\end{array}$ & $\begin{array}{l}\text { A photo electrochemical cell with } \\
\text { ACF cathode }\end{array}$ & 91 & Fe-P & $>90 \%, 12 \mathrm{~h}$ & 41.0 & $\begin{array}{l}\text { Batch, } \mathrm{FeSO}_{4} \text { cost: } \\
5.2 \$ / \mathrm{kg} \mathrm{P}\end{array}$ & $\begin{array}{l}\text { (Zhang } \\
\text { et al., } \\
\text { 2019a) }\end{array}$ \\
\hline $\begin{array}{l}\text { Synthetic wastewater, } 80 \\
\mathrm{mg} / \mathrm{L} \mathrm{HPO}_{3}{ }^{2-}\end{array}$ & $\begin{array}{l}\text { Two anodes (steel and MMO) and } \\
\text { stainless-steel cathode }\end{array}$ & 250 & Fe-P & $74.3 \%, 1 \mathrm{~h}$ & 180.3 & $\begin{array}{l}\text { Batch, oxidation } \\
\text { and coagulation }\end{array}$ & $\begin{array}{l}\text { (Liang et al., } \\
\text { 2019) }\end{array}$ \\
\hline $\begin{array}{l}\text { Synthetic wastewater, } 155 \\
\text { mg/L ortho } P\end{array}$ & $\begin{array}{l}\text { A four-chamber MEC with } \\
\text { stainless-steel mesh cathode }\end{array}$ & $0.72-1.03$ & Ca-P & $80 \%, 16 \mathrm{~h}$ & 2.2 & $\begin{array}{l}\text { Batch, } \mathrm{Ca}^{2+} \text { cost: } \\
0.69-1.06 \$ / \mathrm{kg} \mathrm{P}\end{array}$ & $\begin{array}{l}\text { (Wang et al. } \\
\text { 2020) }\end{array}$ \\
\hline $\begin{array}{l}\text { Domestic wastewater and } \\
\text { spiked extra P, } 7.1 \text { and } \\
23.6 \mathrm{mg} / \mathrm{L} \text { ortho } \mathrm{P}\end{array}$ & $\begin{array}{l}\text { A single cell MEC with Pt-coated Ti } \\
\text { or Ti cathode }\end{array}$ & $1.1-6.6$ & Ca-P & $\begin{array}{l}20-74 \%, 24 \\
\text { h }\end{array}$ & $21-247$ & $\begin{array}{l}\text { Fed-batch, NaAc } \\
\text { supply: } 1-10 \mathrm{mM}\end{array}$ & $\begin{array}{l}\text { (Lei et al., } \\
\text { 2019a) }\end{array}$ \\
\hline $\begin{array}{l}\text { Dewatering concentrate, } \\
13.3 \mathrm{mg} / \mathrm{L} \text { ortho } \mathrm{P}\end{array}$ & A single cell MEC with SSF cathode & $\begin{array}{l}1.2 \mathrm{~V} \text { (fixed } \\
\text { voltage) }\end{array}$ & Struvite & $\begin{array}{l}\text { 79-92\%, } 168 \\
\text { h }\end{array}$ & $2.4-109$ & Fed-batch & $\begin{array}{l}\text { (Yuan and } \\
\text { Kim 2017) }\end{array}$ \\
\hline $\begin{array}{l}\text { Secondary digester effluent, } \\
46 \mathrm{mg} / \mathrm{L} \text { ortho P }\end{array}$ & $\begin{array}{l}\text { A MEC with fluidized bed stainless } \\
\text { steel cathode }\end{array}$ & $0.8-2.4$ & Struvite & $\begin{array}{l}70-85 \% \\
192 \mathrm{~h}\end{array}$ & $6.5-10$ & Fed-batch & $\begin{array}{l}\text { (Cusick } \\
\text { et al., 2014) }\end{array}$ \\
\hline
\end{tabular}


electricity and chemical in the study of Wang et al. (2020) (0.91 \$/kg P) is still comparable with mined phosphate rock, which is around 0.80 $\$ / \mathrm{kg}$ P excluding transportation costs (Kappel et al., 2013). Additionally, the energy cost of electrochemical $\mathrm{P}$ recovery is comparable to CPR (2.6-10.4 \$/kg P) (Daneshgar et al., 2019). These preliminary comparisons indicate that EMP possesses a high potential for recovering $P$. Even though the treatment of non-ortho $\mathrm{P}$ generally requires more energy, the electricity demand could be reduced by combining (bio)electrochemical systems with other technologies, such as photocatalysis (Liang et al., 2019; Zhang et al., 2021; Zhang et al., 2019b). Therefore, it is economically possible to include EMP in the current wastewater-treatment system for removing and recovering P. However, the existing studies on the economic evaluation of the EMP of P minerals mainly consider energy (electricity) consumption, while other costs for scale-up systems, such as electrode materials, reactor materials, and maintenance cost, are not taken into consideration.

Fig. 10 illustrates the impacts of phosphate concentration, the type of $\mathrm{P}$ (ortho or non-ortho, organic or inorganic), the type of electrochemical system (abiotic or biotic, with or without membranes), and the current density on the energy consumption in electrochemical P removal and recovery. The energy consumption largely depends on the phosphate concentration. Overall, systems treating low P-containing wastewater consume more electricity. The typical case is that the electricity consumption per kg Ca-P between the study of Lei et al. (2017) and Perera et al. (2020) was significantly different even though the same current density was applied $\left(3.8 \mathrm{~A} / \mathrm{m}^{2}\right)$. This is due to the much lower P concentration in the former study. Moreover, membranes were used in the study of Perera et al. (2020), which reduced energy consumption because it can more effectively increase the cathodic $\mathrm{pH}$ and lead to better precipitation efficiency. Likewise, similar current density was used in the study of Lei et al. (2019c) and Li et al. (2021b), yet less energy is consumed compared to the previous two studies, resulting from the relatively high initial $\mathrm{P}$ concentration and the presence of $\mathrm{CaCO}_{3}$ or $\mathrm{CaMg}\left(\mathrm{CO}_{3}\right)_{2}$ particles. Additionally, Lei et al. (2021b) elucidated that the system's energy consumption increased with the dilution of P-enriched wastewater, pointing out the importance of performing $\mathrm{P}$ recovery from raw, undiluted cheese wastewater. When $\mathrm{P}$ concentration is too low (typically $<10 \mathrm{mg} / \mathrm{L}$ ), the electricity consumption of EMP for $\mathrm{P}$ recovery is too high to be considered for real applications (Lei et al., 2019a; Lei et al., 2019d). Previous studies on cost evaluation in P recovery via chemical precipitation suggested that the cost is acceptable when the $\mathrm{PO}_{4}-\mathrm{P}$ concentration is above $50 \mathrm{mg} / \mathrm{L}$ (Zhang et al., 2013).

The type of $\mathrm{P}$ also affects the associated energy consumption. The recovery of organic $\mathrm{P}$ usually demands higher energy consumption because it requires a high energy input to break the molecule structure, as shown in the study of Zhang et al. (2021) where $2050 \mathrm{kWh}$ was consumed per $\mathrm{kg}$ P. The treatment of inorganic non-ortho P (i.e., $\mathrm{H}_{2} \mathrm{PO}_{2}{ }^{-}$) may consume less energy. Zhang et al. (2019b) reported that recovering $\mathrm{P}$ from $708 \mathrm{mg} / \mathrm{L}$ electroless nickel plating effluents with $91.0 \mathrm{~A} / \mathrm{m}^{2}$ current supply only needed $41.0 \mathrm{kWh} / \mathrm{kg}$ P. However, due to limited studies, it is hard to draw a solid conclusion regarding the energy consumption in electrochemical $\mathrm{P}$ recovery from inorganic non-ortho-phosphate. Future studies with a wide range of non-ortho-P compounds and concentrations should be performed to draw a convincing comparison between the energy consumption in recovering non-ortho-P compounds.

BES requires less energy input than abiotic ones due to the generation of electrons from exoelectrogenic microbes. Lei et al. (2019a) and Lei et al. (2019d) used bioelectrochemical and abiotic electrochemical systems to treat domestic wastewater, respectively, and the specific energy consumption of the bio-system ( $69 \mathrm{kWh} / \mathrm{kg} \mathrm{P})$ was lower than for the abiotic system $(110 \mathrm{kWh} / \mathrm{kg} \mathrm{P})$. Moreover, the electricity consumption in the studies of Wang et al. (2020) and Cusick et al. (2014), which relied on bioelectrochemical functions, was the lowest. Notably, in the study of Cusick and Logan (2012), the overall energy efficiency of the MEC $\left(\mathrm{H}_{2}\right.$ production vs. electricity and substrate input) is $73 \pm 4 \%$, which indicates that high overall energy efficiency is achievable if the $\mathrm{H}_{2}$ production could be maintained in the (bio)electrochemical system. BES holds great potential in reducing energy consumption, but it often requires additional carbon sources and its working conditions are

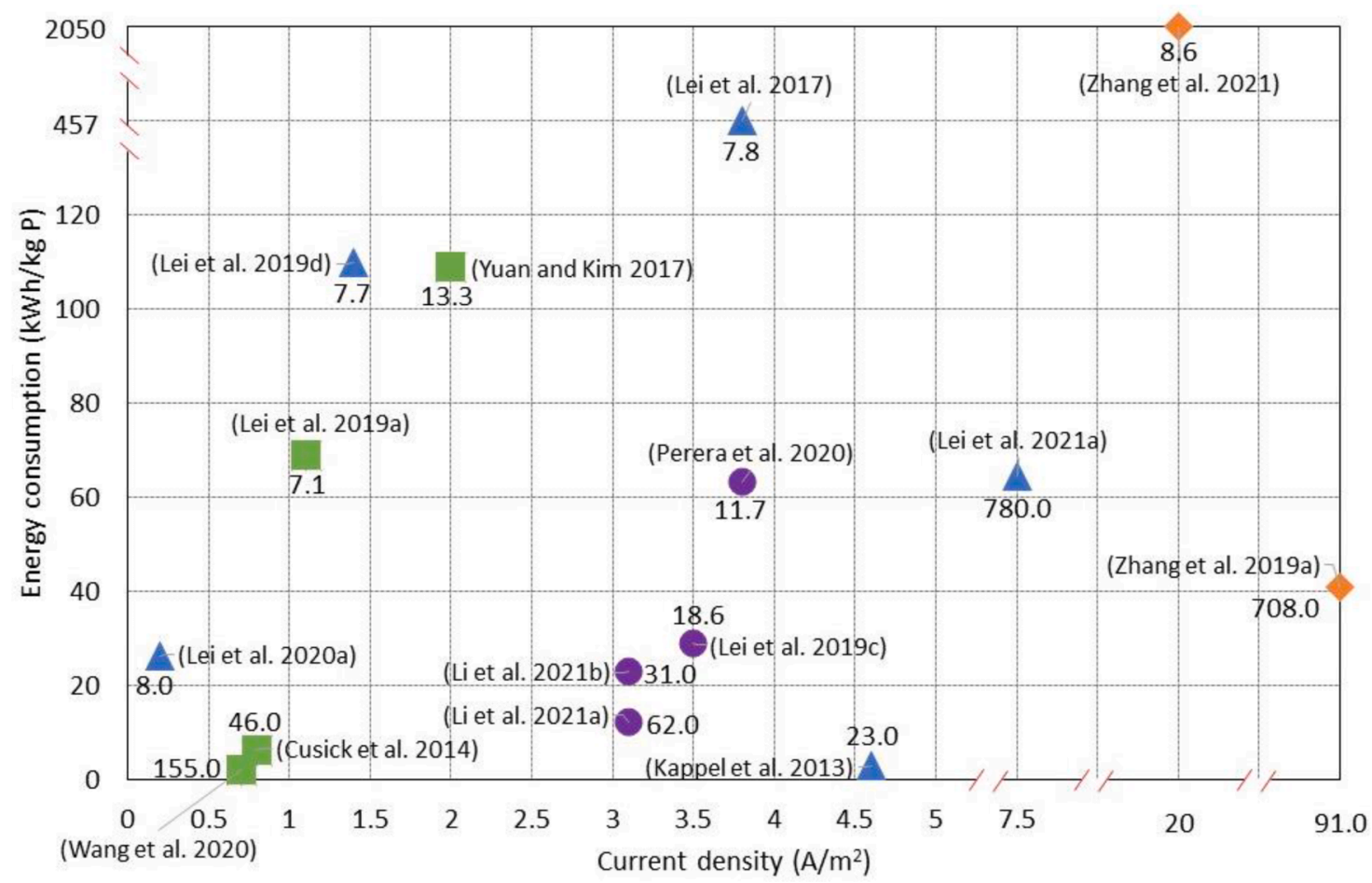

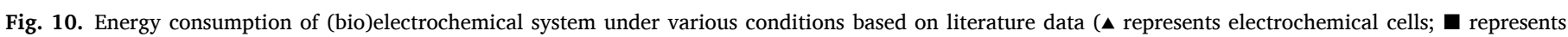

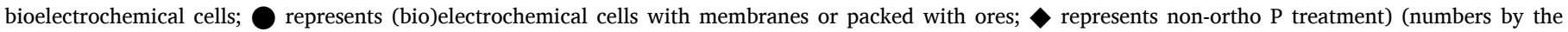
symbols are "initial P concentration, unit: $\mathrm{mg} / \mathrm{L}$ ). 
stricter than abiotic systems.

A higher current density (power input) leads to higher energy consumption, as presented in the study of Lei et al. (2019d) and Lei et al. (2017). Interestingly, in the study of Cusick et al. (2014), the specific energy consumption at $0.8 \mathrm{~V}$ and $1.0 \mathrm{~V}$ was similar $(6.6 \mathrm{kWh} / \mathrm{kg} \mathrm{P})$ because the increased precipitation rate compensated for the increased energy input. However, at $1.4 \mathrm{~V}$, the improved precipitation rate was not sufficient to offset the energy input, leading to enhanced energy consumption (10.0 kWh/kg P). This is due to the formation of crystals on the cathode, which builds a layer and impedes the migration of water $/ \mathrm{H}^{+}$, thus increasing the electrical resistance. Therefore, measures such as regularly harvesting precipitates are required to stabilize the energy efficiency when operating electrochemical $\mathrm{P}$ recovery at a higher current density. The electrode configuration also influences the energy consumption of the systems. Lei et al. (2019c) used $\mathrm{CaCO}_{3}$ to fill up the gap between anode and cathode to treat synthetic wastewater (18.6 $\mathrm{mg} / \mathrm{L} \mathrm{P}$ ) with $3.5 \mathrm{~A} / \mathrm{m}^{2}$ current supply, and the electricity consumption was as low as $29 \mathrm{kWh} / \mathrm{kg} \mathrm{P}$.

Notably, all economic assessments mentioned above excluded the cost of electrodes, membranes, and other constructive facilities. Platinum Group Metal (PGM) coated electrodes (anode) are usually applied in electrochemical systems. This increases the CAPEX of EMP systems significantly when scaling up. The noble metal coated electrode may be replaced with cheaper materials (i.e., graphite), but the durability of non-noble metal electrodes in long-term operation needs further investigation. Consequently, alternative electrode materials or better utilization of PGM coated electrodes should be investigated before scaling up. Furthermore, the use of membranes in electrochemical systems is also a concern because of its monetary cost and maintenance since problems (i.e., fouling and scaling) frequently occur when treating actual wastewater (Barua et al., 2019; Bhambri and Karn, 2020; Kumar et al., 2019; Marassi et al., 2020).

EMP technologies can recover $\mathrm{P}$ in a desirable form without extra chemical dosing, such as Ca-P that can be directly reused as fertilizer. Besides, other valuable by-products can be generated in the electrochemical system, such as hydrogen, which can be captured and utilized to compensate for the energy consumption e.g. as electron donor at the anode (Kuntke et al., 2017). However, the possible monetary reward from by-products has not been systematically studied in the discussed literature. Further research is therefore recommended to assess the total value of electrochemical systems for P recovery. Ideally, an in-depth life cycle assessment, which considers the cost of constructive facilities, the maintenance, the benefit from by-products, and the greenhouse gas footprint, should be performed.

\section{Future perspective}

EMP has emerged as a promising approach to enhance $P$ circularity. A few pilot studies have been conducted to test the stability of EMP at a larger scale. Lei et al. (2021b) designed a $2.8 \mathrm{~L}$ electrochemical reactor with tubular stainless-steel cathode to treat cheese wastewater under long-term (170 days) continuous flow operation mode. The system maintains high stability over the whole operation period. After 173 days of treatment, the reactor was almost filled with precipitates. Happe et al. (2016) constructed a $3 \mathrm{~L}$ triple-chamber MFC to treat digested sewage sludge containing iron phosphate, and $67 \% \mathrm{P}$ was recovered as struvite. Blatter et al. (2020) conducted a pilot test to treat wet sewage sludge containing iron phosphates with a 168 L MEC and 97\% P was recovered. However, to date, most studies have been performed at the laboratory scale. Developments are still needed to address the existing challenges before implementing electrochemical P recovery systems on a large scale.

System optimization for long-term operation should be comprehensively studied. In the lab-scale study, the $\mathrm{P}$ precipitates were directly scraped off the cathode after terminating the reactions, which is inapplicable during continuous operation. Attempts have been made to obtain precipitates while minimizing disturbance on the treatment, such as the hopper reactor design and polarity reversal (Takabe et al., 2020; Varigala et al., 2021). However, innovative product collection designs are still desired, such as detachable electrodes, an automatic scrapper, and the sudden increase of current to detach deposits from the cathode.

The implementation of electrochemical $P$ recovery is casedependent. The wastewater matrix needs to be well-evaluated before considering the application. According to existing studies, electrochemical precipitation is advisable for treating P-rich wastewater, such as dairy wastewater and toilet wastewater. Acidic wastewater is favored because it reduces the co-precipitation of $\mathrm{CaCO}_{3}$ and enhances the purity of recovered products. A database for the wastewater matrix and the corresponding system could be established for research purposes and system optimization. In some industrial wastewaters, such as metal plating industries, non-ortho $\mathrm{P}$ (i.e., hypophosphite) may be the dominant $P$ species. In such cases, electrochemical systems would be a better and promising alternative. However, systematic studies are required to identify the efficiency, energy consumption, and limitations of the EMP process towards the removal and recovery of $\mathrm{P}$ from non-ortho $\mathrm{P}$.

The economic assessment in this paper only considered electricity consumption, which only accounts for part of the system's cost. Solely $\mathrm{P}$ recovery could be expensive compared to commercial $P$ production from phosphate rock. Therefore, integrating EMP of $\mathrm{P}$ minerals into the current wastewater treatment scheme or with other technologies could be a way to compensate for the $\mathrm{P}$ recovery cost. For example, $\mathrm{P}$ recovery could be combined with pollutants removal and $\mathrm{H}_{2}$ or biogas production (Ding et al., 2021; Kuntke et al., 2017; Song et al., 2021). Moreover, the reactor could be redesigned to utilize by-products better. For example, in electrochemical systems, reactive chlorine species can be formed in the presence of chloride ions, which could function as disinfectants. Varigala et al., 2021 used chlorine produced in electrochemical cells for on-site disinfection of treated blackwater.

Ultimately, the acceptance of the recovered product should be considered. Even though P recovered from wastewater usually is cleaner than $P$ rock, it may cause concerns from public and fertilizer manufacturers, especially when the product is recovered from heavy metalsloaded or micro-organic pollutants-burdened wastewater. Thus, how to build up trust and confidence in the products is also a question needed to be answered.

\section{Conclusion}

EMP systems hold vast potential in removing and recovering $\mathrm{P}$, either ortho or non-ortho P. The main reasons are: (a) it is technically feasible to remove $\mathrm{P}$ in wastewater to the required level and recover $\mathrm{P}$ as effective fertilizers through (bio)electrochemical precipitation; (b) onsite treatment is possible without dosing extra chemicals; (c) the monetary cost of (bio)electrochemical system could be comparable with conventional P-treating technologies in theory. Yet, it is important to acknowledge that multiple factors affect the system's performance, including $\mathrm{pH}$, current density, electrode configuration, and water matrix. Currently, there are questions needed to be answered before applying EMP systems at full scale, such as system stability under longterm operation, system output under different water matrices, and energy consumption of scale-up reactor. Additionally, more research is needed to improve the utilization of by-products, the collection of deposits, the wastewater assessment for on-site application, and the acceptance of products of electrochemical P recovery. Moreover, further studies are required to explore the long-term operation of EMP in P removal and recovery at a large scale and make the process economical and practical soundable.

\section{Declaration of Competing Interest}

The authors declare that they have no known competing financial interests or personal relationships that could have appeared to influence 
the work reported in this paper.

\section{Acknowledgments}

This work was partially performed in the cooperation framework of Wetsus, European Centre of Excellence for Sustainable Water Technology (www.wetsus.eu). Wetsus is co-funded by the Dutch Ministry of Economic Affairs and Ministry of Infrastructure and Environment, the European Union Regional Development Fund, the Province of Fryslân, and the Northern Netherlands Provinces. This research has received partial funding from NWO (The Dutch Research Council) under the NWO Take-off grant agreement No 18283. The authors like to thank the participants of the research theme "Resource Recovery" for the fruitful discussions and their financial support.

\section{References}

Almatouq, A., Babatunde, A.O., 2016. Concurrent phosphorus recovery and energy generation in mediator-less dual chamber microbial fuel cells: mechanisms and influencing factors. Int. J. Environ. Res. Public Health 13 (4), 375.

Barua, S., Zakaria, B.S., Chung, T., Hai, F.I., Haile, T., Al-Mamun, A., Dhar, B.R., 2019. Microbial electrolysis followed by chemical precipitation for effective nutrients recovery from digested sludge centrate in WWTPs. Chem. Eng. J. 361, 256-265.

Belarbi, Z., Daramola, D.A., Trembly, J.P., 2020. Bench-scale demonstration and thermodynamic simulations of electrochemical nutrient reduction in wastewater via recovery as struvite. J. Electrochem. Soc. 167 (15), 155524.

Bhambri, A., Karn, S.K., 2020. Biotechnique for nitrogen and phosphorus removal: a possible insight. Chem. Ecol. 1-25.

Blatter, M., Furrer, C., Cachelin, C.P., Fischer, F., 2020. Phosphorus, chemical base and other renewables from wastewater with three 168-L microbial electrolysis cells and other unit operations. Chem. Eng. J. 390, 124502.

Blatter, M., Vermeille, M., Furrer, C., Pouget, G., Fischer, F., 2019. Mechanisms and model process parameters in bioelectrochemical wet phosphate recovery from iron phosphate sewage sludge. ACS Sustain. Chem. Eng. 7 (6), 5856-5866.

Brooker, M., Longnecker, K., Kujawinski, E., Evert, M., Mouser, P., 2018. Discrete organic phosphorus signatures are evident in pollutant sources within a Lake Erie tributary. Environ. Sci. Technol. 52 (12), 6771-6779.

Cao, X., Harris, W., 2008. Carbonate and magnesium interactive effect on calcium phosphate precipitation. Environ. Sci. Technol. 42 (2), 436-442.

Chen, M., Graedel, T., 2016. A half-century of global phosphorus flows, stocks, production, consumption, recycling, and environmental impacts. Global Environ. Change 36, 139-152.

Chen, M., Li, X., Zhang, Q., Wang, C., Hu, H., Wang, Q., Zeng, C., 2021. Phosphate removal from aqueous solution by electrochemical coupling siderite packed column. Chemosphere 280, 130805.

Cid, C.M.A., Jasper, J.T., Hoffmann, M.R., 2018. Phosphate recovery from human waste via the formation of hydroxyapatite during electrochemical wastewater treatment. ACS Sustain. Chem. Eng. 6 (3), 3135-3142.

Cordell, D., Drangert, J.O., White, S., 2009. The story of phosphorus: global food security and food for thought. Global Environ. Change 19 (2), 292-305.

Cornel, P., Schaum, C., 2009. Phosphorus recovery from wastewater: needs, technologies and costs. Water Sci. Technol. 59 (6), 1069-1076.

Crini, G., Lichtfouse, E., Wilson, L.D., Morin-Crini, N., 2019. Conventional and nonconventional adsorbents for wastewater treatment. Environ. Chem. Lett. 17 (1), 195-213.

Cusick, R.D., Kiely, P.D., Logan, B.E., 2010. A monetary comparison of energy recovered from microbial fuel cells and microbial electrolysis cells fed winery or domestic wastewaters. Int. J. Hydrogen Energy 35 (17), 8855-8861.

Cusick, R.D., Logan, B.E., 2012. Phosphate recovery as struvite within a single chamber microbial electrolysis cell. Bioresour. Technol. 107, 110-115.

Cusick, R.D., Ullery, M.L., Dempsey, B.A., Logan, B.E., 2014. Electrochemical struvite precipitation from digestate with a fluidized bed cathode microbial electrolysis cell. Water Res. 54, 297-306.

Daneshgar, S., Buttafava, A., Callegari, A., Capodaglio, A.G., 2019. Economic and energetic assessment of different phosphorus recovery options from aerobic sludge. J. Cleaner Prod. 223, 729-738.

Desmidt, E., Ghyselbrecht, K., Zhang, Y., Pinoy, L., Van der Bruggen, B., Verstraete, W., Rabaey, K., Meesschaert, B., 2015. Global phosphorus scarcity and full-scale Precovery techniques: a review. Crit. Rev. Environ. Sci. Technol. 45 (4), 336-384.

Ding, L., Lin, H., Zamalloa, C., Hu, B., 2021. Simultaneous phosphorus recovery, sulfide removal, and biogas production improvement in electrochemically assisted anaerobic digestion of dairy manure. Sci. Total Environ. 777, 146226.

Egle, L., Rechberger, H., Krampe, J., Zessner, M., 2016. Phosphorus recovery from municipal wastewater: an integrated comparative technological, environmental and economic assessment of P recovery technologies. Sci. Total Environ. 571, 522-542.

Feng, Y., Yang, L., Liu, J., Logan, B.E., 2016. Electrochemical technologies for wastewater treatment and resource reclamation. Environ. Sci.: Water Res. Technol. 2 (5), 800-831.

Fischer, F., Bastian, C., Happe, M., Mabillard, E., Schmidt, N., 2011. Microbial fuel cell enables phosphate recovery from digested sewage sludge as struvite. Bioresour. Technol. 102 (10), 5824-5830.
Food and Nations, A.O.O.T.U, 2019. World Fertilizer Trends and Outlook to 2022. Food and Agriculture Organization of the United Nations Rome, Italy.

Foroughi, F., Kékedy-Nagy, L., Islam, M.H., Lamb, J.J., Greenlee, L.F., Pollet, B.G., 2019. The use of ultrasound for the electrochemical synthesis of magnesium ammonium phosphate hexahydrate (Struvite). ECS Trans. 92 (10), 47-55.

Garcia-Segura, S., Ocon, J.D., Chong, M.N., 2018. Electrochemical oxidation remediation of real wastewater effluents-A review. Process Saf. Environ. Prot. 113, 48-67.

Ghosh, S., Lobanov, S., Lo, V.K., 2019. An overview of technologies to recover phosphorus as struvite from wastewater: advantages and shortcomings. Environ. Sci. Pollut. Res. 1-15.

Gifford, M., Liu, J., Rittmann, B.E., Vannela, R., Westerhoff, P., 2015. Phosphorus recovery from microbial biofuel residual using microwave peroxide digestion and anion exchange. Water Res. 70, 130-137.

Guedes, P., Couto, N., Ottosen, L.M., Ribeiro, A.B., 2014. Phosphorus recovery from sewage sludge ash through an electrodialytic process. Waste Manag. 34 (5), 886-892.

Happe, M., Sugnaux, M., Cachelin, C.P., Stauffer, M., Zufferey, G., Kahoun, T., Salamin, P.A., Egli, T., Comninellis, C., Grogg, A.F., 2016. Scale-up of phosphate remobilization from sewage sludge in a microbial fuel cell. Bioresour. Technol. 200, 435-443.

Hirooka, K., Ichihashi, O., 2013. Phosphorus recovery from artificial wastewater by microbial fuel cell and its effect on power generation. Bioresour. Technol. 137, $368-375$.

Huang, H., Zhang, P., Zhang, Z., Liu, J., Xiao, J., Gao, F., 2016. Simultaneous removal of ammonia nitrogen and recovery of phosphate from swine wastewater by struvite electrochemical precipitation and recycling technology. J. Cleaner Prod. 127, 302-310.

Hug, A., Udert, K.M., 2013. Struvite precipitation from urine with electrochemical magnesium dosage. Water Res. 47 (1), 289-299.

Ichihashi, O., Hirooka, K., 2012. Removal and recovery of phosphorus as struvite from swine wastewater using microbial fuel cell. Bioresour. Technol. 114, 303-307.

Jasinski, S.M., 2020. U.S. Geological Survey, 2020. Mineral Commodity Summaries. January.

Jupp, A.R., Beijer, S., Narain, G.C., Schipper, W., Slootweg, J.C., 2021. Phosphorus recovery and recycling-closing the loop. Chem. Soc. Rev. 50, 87-101.

Kappel, C., Yasadi, K., Temmink, H., Metz, S., Kemperman, A.J., Nijmeijer, K., Zwijnenburg, A., Witkamp, G.J., Rijnaarts, H., 2013. Electrochemical phosphate recovery from nanofiltration concentrates. Sep. Purif. Technol. 120, 437-444.

Karunanithi, R., Szogi, A.A., Bolan, N., Naidu, R., Loganathan, P., Hunt, P.G., Vanotti, M. B., Saint, C.P., Ok, Y.S., Krishnamoorthy, S., 2015. Advances in Agronomy. Academic Press, pp. 173-250. Sparks, D.L.ed.

Kumar, S.S., Kumar, V., Malyan, S.K., Sharma, J., Mathimani, T., Maskarenj, M.S. Ghosh, P.C., Pugazhendhi, A., 2019. Microbial fuel cells (MFCs) for bioelectrochemical treatment of different wastewater streams. Fuel 254, 115526.

Kuntke, P., Rodríguez Arredondo, M., Widyakristi, L., ter Heijne, A., Sleutels, T.H., Hamelers, H.V., Buisman, C.J., 2017. Hydrogen gas recycling for energy efficient ammonia recovery in electrochemical systems. Environ. Sci. Technol. 51 (5), 3110-3116.

Lei, Y., Du, M., Kuntke, P., Saakes, M., van der Weijden, R., Buisman, C.J., 2019a. Energy efficient phosphorus recovery by microbial electrolysis cell induced calcium phosphate precipitation. ACS Sustain. Chem. Eng. 7 (9), 8860-8867.

Lei, Y., Geraets, E., Saakes, M., van der Weijden, R.D., Buisman, C.J., 2020a. Electrochemical removal of phosphate in the presence of calcium at low current density: precipitation or adsorption? Water Res. 169, 115207.

Lei, Y., Hidayat, I., Saakes, M., van der Weijden, R., Buisman, C.J., 2019b. Fate of calcium, magnesium and inorganic carbon in electrochemical phosphorus recovery from domestic wastewater. Chem. Eng. J. 362, 453-459.

Lei, Y., Narsing, S., Saakes, M., Van Der Weijden, R.D., Buisman, C.J., 2019c. Calcium carbonate packed electrochemical precipitation column: new concept of phosphate removal and recovery. Environ. Sci. Technol. 53 (18), 10774-10780.

Lei, Y., Remmers, J.C., Saakes, M., van der Weijden, R.D., Buisman, C.J., 2018a. Is there a precipitation sequence in municipal wastewater induced by electrolysis? Environ. Sci. Technol. 52 (15), 8399-8407.

Lei, Y., Remmers, J.C., Saakes, M., Van Der Weijden, R.D., Buisman, C.J., 2019d. Influence of cell configuration and long-term operation on electrochemical phosphorus recovery from domestic wastewater. ACS Sustain. Chem. Eng. 7 (7), 7362-7368.

Lei, Y., Saakes, M., Van Der Weijden, R.D., Buisman, C.J., 2018b. Effects of current density, bicarbonate and humic acid on electrochemical induced calcium phosphate precipitation. Chem. Eng. J. 342, 350-356.

Lei, Y., Saakes, M., van der Weijden, R.D., Buisman, C.J., 2020b. Electrochemically mediated calcium phosphate precipitation from phosphonates: implications on phosphorus recovery from non-orthophosphate. Water Res. 169, 115206.

Lei, Y., Song, B., Saakes, M., Van Der Weijden, R.D., Buisman, C.J., 2018c. Interaction of calcium, phosphorus and natural organic matter in electrochemical recovery of phosphate. Water Res. 142, 10-17.

Lei, Y., Song, B., van der Weijden, R.D., Saakes, M., Buisman, C.J., 2017. Electrochemical induced calcium phosphate precipitation: importance of local pH. Environ. Sci. Technol. 51 (19), 11156-11164.

Lei, Y., Zhan, Z., Saakes, M., van der Weijden, R.D., Buisman, C.J., 2021a. Electrochemical recovery of phosphorus from acidic cheese wastewater: feasibility, quality of products, and comparison with chemical precipitation. ACS EST Water 1 (4), 1002-1013.

Lei, Y., Zhan, Z., Saakes, M., van der Weijden, R.D., Buisman, C.J.N., 2021 b. Electrochemical recovery of phosphorus from wastewater using tubular stainlesssteel cathode for a scalable long-term operation. Water Res. 199, 117199. 
Li, B., Udugama, I.A., Mansouri, S.S., Yu, W., Baroutian, S., Gernaey, K.V., Young, B.R., 2019. An exploration of barriers for commercializing phosphorus recovery technologies. J. Clean. Prod. 229, 1342-1354.

Li, N., Wan, Y., Wang, X., 2020. Nutrient conversion and recovery from wastewater using electroactive bacteria. Sci. Total Environ. 706, 135690.

Li, X., Zhao, X., Zhou, X., Yang, B., 2021a. Phosphate recovery from aqueous solution via struvite crystallization based on electrochemical-decomposition of nature magnesite. J. Cleaner Prod. 292, 126039.

Li, X., Zhou, X., Yang, B., Wen, Z., 2021b. Recovery phosphate and ammonium from aqueous solution by the process of electrochemically decomposing dolomite. Chemosphere 262, 128357.

Liang, S., Zheng, W., Zhu, L., Duan, W., Wei, C., Feng, C., 2019. One-step treatment of phosphite-laden wastewater: a single electrochemical reactor integrating superoxide radical-induced oxidation and electrocoagulation. Environ. Sci. Technol. 53 (9), 5328-5336.

Liu, W., Ciais, P., Liu, X., Yang, H., Hoekstra, A.Y., Tang, Q., Wang, X., Li, X., Cheng, L., 2020a. Global phosphorus losses from croplands under future precipitation scenarios. Environ. Sci. Technol. 54 (22), 14761-14771.

Liu, Y., Deng, Y.Y., Zhang, Q., Liu, H., 2020b. Overview of recent developments of resource recovery from wastewater via electrochemistry-based technologies. Sci. Total Environ. 757, 143901.

Logan, B.E., Call, D., Cheng, S., Hamelers, H.V., Sleutels, T.H., Jeremiasse, A.W., Rozendal, R.A., 2008. Microbial electrolysis cells for high yield hydrogen gas production from organic matter. Environ. Sci. Technol. 42 (23), 8630-8640.

Logan, B.E., Hamelers, B., Rozendal, R., Schröder, U., Keller, J., Freguia, S., Aelterman, P., Verstraete, W., Rabaey, K., 2006. Microbial fuel cells: methodology and technology. Environ. Sci. Technol. 40 (17), 5181-5192.

Lu, X., Zhao, Z., Leng, Y., 2005. Calcium phosphate crystal growth under controlled atmosphere in electrochemical deposition. J. Cryst. Growth 284, 506-516, 3-4.

Marassi, R., Queiroz, L., Silva, D., Dos Santos, F., Silva, G., de Paiva, T, 2020. Long-term performance and acute toxicity assessment of scaled-up air-cathode microbial fuel cell fed by dairy wastewater. Bioprocess Biosyst. Eng. 43 (9).

Mayer, B.K., Baker, L.A., Boyer, T.H., Drechsel, P., Gifford, M., Hanjra, M.A., Parameswaran, P., Stoltzfus, J., Westerhoff, P., Rittmann, B.E., 2016. Total value of phosphorus recovery. Environ. Sci. Technol. 50 (13), 6606-6620.

Melia, P.M., Cundy, A.B., Sohi, S.P., Hooda, P.S., Busquets, R., 2017. Trends in the recovery of phosphorus in bioavailable forms from wastewater. Chemosphere 186 381-395.

Modin, O., Gustavsson, D.J., 2014. Opportunities for microbial electrochemistry in municipal wastewater treatment-an overview. Water Sci. Technol. 69 (7), 1359-1372.

Muddemann, T., Haupt, D., Sievers, M., Kunz, U., 2019. Electrochemical reactors for wastewater treatment. ChemBioEng Rev. 6 (5), 142-156.

Nancharaiah, Y., Mohan, S.V., Lens, P., 2016. Recent advances in nutrient removal and recovery in biological and bioelectrochemical systems. Bioresour. Technol. 215, $173-185$.

Nielsen, A., 1969. Ultraviolet spectra and structure of complexes of pyridine 1-oxide and oxygen acids. Krist. Tech. 4, 17.

Pepè Sciarria, T., Vacca, G., Tambone, F., Trombino, L., Adani, F, 2019. Nutrient recovery and energy production from digestate using microbial electrochemical technologies (METs). J. Clean. Prod. 208, 1022-1029.

Perera, M.K., Englehardt, J.D., Cohn, J.L., Dauer, E.A., Shukla, D, 2020 Electrohydromodulation for phosphate recovery from wastewater. Sep. Purif. Technol. 247, 116909.

Perera, M.K., Englehardt, J.D., Dvorak, A.C., 2019. Technologies for recovering nutrients from wastewater: a critical review. Environ. Eng. Sci. 36 (5), 511-529.

Pocostales, J.P., Sein, M.M., Knolle, W., von Sonntag, C., Schmidt, T.C., 2010. Degradation of ozone-refractory organic phosphates in wastewater by ozone and ozone/hydrogen peroxide (peroxone): the role of ozone consumption by dissolved organic matter. Environ. Sci. Technol. 44 (21), 8248-8253.

Rott, E., Minke, R., Bali, U., Steinmetz, H., 2017. Removal of phosphonates from industrial wastewater with UV/FeII, Fenton and UV/Fenton treatment. Water Res. 122, 345-354.

Schaum, C., 2018. Phosphorus: Polluter and Resource of the Future: Motivations, Technologies and Assessment of the Elimination and Recovery of Phosphorus from Wastewater. IWA Publishing.

Shaddel, S., Ucar, S., Andreassen, J.P., Østerhus, S.W., 2019. Enhancing efficiency and economics of phosphorus recovery process by customizing the product based on sidestream characteristics-an alternative phosphorus recovery strategy. Water Sci. Technol. 79 (9), 1777-1789.
Sindelar, H.R., Lloyd, J., Brown, M.T., Boyer, T.H., 2016. Transformation of dissolved organic phosphorus to phosphate using UV/H2O2. Environ. Prog. Sustainable Energy 35 (3), 680-691.

Sø, H.U., 2011. Adsorption of Arsenic and Phosphate Onto the Surface of Calcite As Revealed by Batch Experiments and Surface Complexation Modelling. Technical University of Denmark.

Song, Y.H., Hidayat, S., Effendi, A.J., Park, J.Y., 2021. Simultaneous hydrogen production and struvite recovery within a microbial reverse-electrodialysis electrolysis cell. J. Ind. Eng. Chem. 94, 302-308.

Srivastava, P., Abbassi, R., Yadav, A.K., Garaniya, V., Jahromi, M.A.F., 2020. A review on the contribution of an electron in electroactive wetlands: electricity generation and enhanced wastewater treatment. Chemosphere 254, 126926.

Sun, S., Wang, S., Ye, Y., Pan, B., 2019. Highly efficient removal of phosphonates from water by a combined Fe (III)/UV/co-precipitation process. Water Res. 153, 21-28.

Tabassum, N., Islam, N., Ahmed, S., 2021. Progress in microbial fuel cells for sustainable management of industrial effluents. Process Biochem. 106, 20-41.

Takabe, Y., Ota, N., Fujiyama, M., Okayasu, Y., Yamasaki, Y., Minamiyama, M., 2020. Utilisation of polarity inversion for phosphorus recovery in electrochemical precipitation with anaerobic digestion effluent. Sci. Total Environ. 706, 136090.

Tao, Q., Luo, J., Zhou, J., Zhou, S., Liu, G., Zhang, R., 2014. Effect of dissolved oxygen on nitrogen and phosphorus removal and electricity production in microbial fuel cell. Bioresour. Technol. 164, 402-407.

Wang, C.C., Hao, X.D., Guo, G.S., Van Loosdrecht, M., 2010. Formation of pure struvite at neutral pH by electrochemical deposition. Chem. Eng. J. 159 (1-3), 280-283.

Varigala, S., Krishnaswamy, S., Lohia, C.P., Hegarty-Craver, M., Grego, S., Luettgen, M., Cid, C.A., 2021. Optimal Design of an Electrochemical Reactor For Blackwater Treatment. Water Environment Research 93 (1), 148-158.

Wang, L., Gu, K., Zhang, Y., Sun, J., Gu, Z., Zhao, B., Hu, C., 2022. Enhanced struvite generation and separation by magnesium anode electrolysis coupled with cathode electrodeposition. Sci. Total Environ. 804, 150101.

Wang, M., Ma, L., Strokal, M., Ma, W., Liu, X., Kroeze, C., 2018. Hotspots for nitrogen and phosphorus losses from food production in China: a county-scale analysis. Environ. Sci. Technol. 52 (10), 5782-5791.

Wang, Z., Zhang, J., Guan, X., She, L., Xiang, P., Xia, S., Zhang, Z., 2019. Bioelectrochemical acidolysis of magnesia to induce struvite crystallization for recovering phosphorus from aqueous solution. J. Environ.Sci. 85, 119-128.

Wang, Z., Zhang, J., Hu, X., Bian, R., Xv, Y., Deng, R., Zhang, Z., Xiang, P., Xia, S., 2020. Phosphorus recovery from aqueous solution via a microbial electrolysis phosphorusrecovery cell. Chemosphere 257, 127283.

Ye, Y., Ngo, H.H., Guo, W., Chang, S.W., Nguyen, D.D., Liu, Y., Nghiem, L.D., Zhang, X., Wang, J., 2019a. Effect of organic loading rate on the recovery of nutrients and energy in a dual-chamber microbial fuel cell. Bioresour. Technol. 281, 367-373.

Ye, Y., Ngo, H.H., Guo, W., Liu, Y., Chang, S.W., Nguyen, D.D., Ren, J., Liu, Y., Zhang, X., 2019b. Feasibility study on a double chamber microbial fuel cell for nutrient recovery from municipal wastewater. Chem. Eng. J. 358, 236-242.

Ye, Y., Ngo, H.H., Guo, W., Liu, Y., Li, J., Liu, Y., Zhang, X., Jia, H., 2017. Insight into chemical phosphate recovery from municipal wastewater. Sci. Total Environ. 576, $159-171$.

Yuan, P., Kim, Y., 2017. Increasing phosphorus recovery from dewatering centrate in microbial electrolysis cells. Biotechnol. Biofuels 10 (1), 70.

Yuan, Z., Jiang, S., Sheng, H., Liu, X., Hua, H., Liu, X., Zhang, Y., 2018. Human perturbation of the global phosphorus cycle: changes and consequences. Environ. Sci. Technol. 52 (5), 2438-2450.

Zhang, J., Zhao, X., Wang, Y., Djellabi, R., 2019a. Recovery of phosphorus fromhypophosphite-laden wastewater: a single-compartment photoelectrocatalytic cellsystem integrating oxidation and precipitation. Environ. Sci. Technol. 54 (2), 1204-1213.

Zhang, Q., Ba, X., Liu, S., Li, Y., Cai, L., Sun, H., Jiang, B., 2021. Synchronous anodic oxidation-cathodic precipitation strategy for efficient phosphonate wastes mineralization and recovery of phosphorus in the form of hydroxyapatite. Sep. Purif, Technol. 272, 118895.

Zhang, X., Li, J., Fan, W.Y., Sheng, G.P., 2019b. Photomineralization of effluent organic phosphorus to orthophosphate under simulated light illumination. Environ. Sci. Technol. 53 (9), 4997-5004.

Zhang, Y., Desmidt, E., Van Looveren, A., Pinoy, L., Meesschaert, B., Van der Bruggen, B., 2013. Phosphate separation and recovery from wastewater by novel electrodialysis. Environ. Sci. Technol. 47 (11), 5888-5895.

Zhang, Z., She, L., Zhang, J., Wang, Z., Xiang, P., Xia, S., 2019c. Electrochemical acidolysis of magnesite to induce struvite crystallization for recovering phosphorus from aqueous solution. Chemosphere 226, 307-315. 